ISSN:1308-8173

Geliş Tarihi: 10.09 .2020
E-ISSN: 1308-8505

Kabul Tarihi: 09.09.2021
YIL: 2022

Online Yayın: 02.03.2022

ÖZGÜN ARAŞTIRMA
Cilt: 37 Sayı: 1 Sayfa: 53-76

Doi: $10.24988 /$ ije.793444

\title{
Finans İşletmelerinin Stratejik Yönetim Bağlamında Misyon ve Vizyon İfadesi Bileşenlerine Göre Girişimcilik Özellikleri
}

\author{
Necla KUDUZ 1 , Mesut ATASEVER ${ }^{2}$ \\ Özet
}

Misyon bir işletmenin var oluş nedeni olarak tanımlanırken, vizyon; bir işletmenin gelecekte ulaşmak istediği yerin bir görüntüsü olarak tanımlanmaktadır. Isşletmeler misyon ve vizyon ifadelerini oluştururken amaç ve hedeflerini, stratejilerini, değerlerini, ağırlıklı olarak önem verdikleri konuları ve yanı sıra girişimcilik özelliklerini de yansıtmaktadır. Girişimcilik özellikleri, girişimcinin davranışsal özelliklerinden etkilenmekle beraber, literatürde dokuz boyuttan oluştuğu bilinmektedir. Bunlar; risk alma, liderlik, yenilikçilik, yaratıcılık, güçlülük, proaktiflik, araştırma ve geliştirme, başarı ve rekabetçilik gibi kavramlardır. Isşletmeler misyon ve vizyon ifadelerinde bu kavramları kullanarak işletmenin yönü, işletmenin değerleri, girişimcilik özellikleri hakkında bilgi vermektedirler. Isşletmelerin, stratejik yönetim ifadelerinde gerçekçi davranmaması, bu ifadelerin girişimcilik özelliklerini yansıtacak biçimde oluşturmamaları, ayrıca işletme gerçeklerinden uzak, taklit ifadeler kullanmaları problem olarak görülmektedir. Bu çalışmada işletmelerin misyon ve vizyon ifadelerini gerçekçi, işletme gerçekleriyle örtüşecek biçimde ve ciddi olarak oluşturdukları varsayılmıştır. Bu çalışmanın amacı, ağustos-2020 misyon ve vizyon ifadeleri baz alınarak, Türkiye Bankalar Birliği (TBB)'nde paylaşılmış olan (kalkınma ve sınai bankaları hariç) banka ve finans işletmelerinin web sitelerinde paylaşılmış olan misyon ve vizyon ifadelerinden yola çlkarak finans işletmelerinin girişimcilik özelliklerini tespit ederek yorumlamaya çalışmaktır. Bu amaçla, ifadeler girişimcilik özellikleri bakımından nitel olarak değerlendirilmiştir, bu doğrultuda TBB'nin web sitesinde paylaşımda bulunan banka ve finans işletmelerinin girişimcilik özellikleri, stratejik yönetim ifadelerinde yer alan anlamlı faktörler olarak gözlemlenmiştir. Bu çalışmanın, stratejik yönetim ve girişimcilik özelliklerinin ayrılamaz bileşenler olduğunun belirginleşmesi bakımından önemli olduğu düşünülmektedir. Ayrıca çalışmanın ilgili sektör yöneticilerine, girişimcilik ve stratejik yönetim alanında çalışan akademisyenlere yararlı olması beklenmektedir.

Anahtar Kelimeler: Girişimcilik, Stratejik Yönetim, Misyon, Vizyon, Finans

Jel Sinıflandırması: $L 21, L 25, G 10, M 30$

\section{Entrepreneurship Characteristics Of Financial Enterprises According To The Mission And Vision Expression Components In The Context Of Strategic Management}

\section{Abstract}

While the mission defines the reason for the existence of a business, the vision; It is defined as an image of the place that a business wants to reach in the future. While establishing their mission and vision statements, businesses reflect their goals and objectives, strategies, values, and entrepreneurship characteristics, as well as the subjects they mainly care about. Although entrepreneurship characteristics are influenced by the entrepreneur's behavioral characteristics, it is known that it consists of nine dimensions in the literature. These; concepts such as risk-taking, leadership, innovativeness, creativity, strength, proactivity, research and development, success and competitiveness. Businesses provide information about the direction of the business, the values of the business, and the entrepreneurial characteristics by using these concepts in their mission and vision statements. It is seen as a problem that businesses do not behave realistically in their strategic management expressions, do not create these expressions in a way to reflect their entrepreneurial characteristics, and also use imitation expressions that are far from business realities. In this study, it is assumed that the companies form their mission and vision statements realistic, in line with the business realities and seriously. The purpose of this study, August 2020 statements taken, the Banks Association of Turkey (TBB) in the published which (excluding development and industrial banks) banks and finance in the business of websites based on their shared that mission and vision statements finance and business to try to interpret by detecting the entrepreneurial characteristics. For this purpose, the statements were evaluated qualitatively in terms of entrepreneurship characteristics. In this direction, the entrepreneurship characteristics of banks and financial enterprises published on the website of TBB were observed as significant factors included in the strategic management expressions. This study is considered to be important in terms of making it clear that

ATIF ÖNERÍsí (APA): Kuduz, N., Atasever, M. (2022). Finans İşletmelerinin Stratejik Yönetim Bağlamında Misyon ve Vizyon İfadesi Bileşenlerine Göre Girişimcilik Özellikleri. İzmir İktisat Dergisi. 37(1). 53-76. Doi: 10.24988/ije.793444 ${ }^{1}$ Dr. Öğr Üyesi, Uşak Üniversitesi, Uygulamalı Bilimler Fakültesi, UŞAK, EMAIL: necla.kuduz@usak.edu.tr, ORCID:00000002-7910-3314

2 Dr. Öğr Üyesi, Uşak Üniversitesi, Uygulamalı Bilimler Fakültesi, UŞAK, EMAIL: mesut.atasever@usak.edu.tr ORCID:0000-0002-7189-7551 
strategic management and entrepreneurship features are inseparable components. In addition, the study is expected to be beneficial for the relevant sector managers, and academicians working in the field of entrepreneurship and strategic management.

Keywords: Entrepreneurship, Strategic Management, Mission, Vision, Finance

Jel Classification: L21, L25, G10, M30

\section{GíRiș}

Tarihin ilk çağlarından bu yana insanoğlu hayatta kalmak ve yaşamını devam ettirmek için doğadaki kaynakları bir araya getirerek, gerek insan gücü gerek makinelerden faydalanarak üretme eyleminde bulunmuştur. Girişim; insan ihtiyaçlarını karşılamak üzere sahibinin özel varlığından ayrı bir yer, unvan, sermaye, muhasebe ve organizasyon olarak bir bütün oluşturan ve devamlı üretim faaliyetinde bulunan, ekonomik bir birim olarak ifade edilmektedir (Şimşek ve Çelik, 2012, s.11). Girişimcilik kavramı ilk kez 18. Yüzyılda Richard Cantillon tarafından kullanılmıștır. Cantillon girişimciyi; önceden belirlenmemiş bir bedelle satmak üzere üretim ve hizmet girdilerini bugünden satın alan ve üreten kişi olarak tanımlanmıştır (İraz, 2005: 149).Daha soyut açıdan ele alındığında, işin öznesi olan girişimcinin iş kurma süreçlerinde ortaya koydukları çaba ve katlandıkları zorlukların bütünü olarak tanımlanmaktadır (Tutar ve Küçük, 2003: 56). Girişimcilik aynı zamanda gelişmekte olan ekonomilerin büyümeleri için zaruri bir ihtiyaç olup; bu olgu bugün için gelişmiş ekonomiler de dahil olmak üzere küresel bir kavramdır (Zoltan vd., 2001: 235-245). Schumpeter "The Theory of Economic Development" adlı kitabında girişimciyi yeniliği sunan birey olarak tanımlayarak girişimcilik teorisine en önemli ve en bilinen katkıyı sağlamıştır denilebilir (Aidis, 2003: 4). Girişimcilerin taşıdıkları kişilik özellikleri birçok farklı yazar tarafından farklı şekilde ifade edilmiştir. Yenilikçi (Herron, 1992; Geisler, 1993; Drucker, 1998; Daft, 2005; Hisrich vd., 2005; Hitt vd., 2005; Küçük, 2005), risk alan (Geisler, 1993; Johnson /Hayes, 1996; Drucker, 1998; Hisrich vd., 2005; Hitt vd., 2005; Küçük, 2005; Zhao vd., 2005; Hewison/Badger, 2006), değişim odaklı (Luchsinger/Bagby, 1987; Herron, 1992; Hisrich vd., 2005; Hitt vd., 2005), firsatlara odaklanmış (Corbett/Hmieleski, 2005; Hitt vd., 2005) ve yaratıcı (Daft, 2005; Hitt vd., 2005; Hewison/Badger, 2006) oldukları belirtilmiştir. Bunların yanında girişimcilerin sahip olduğu özelliklerle ilgili olarak, daha düşük oranda, gelişmiş iletişim becerisi (Hitt vd., 2005), proaktiflik (Hisrich vd., 2005), vicdanlılık (conscientiousness), yüksek başarı güdüsü (Daft, 2005) ve kararlarında ısrarcı olma (Hitt vd., 2005) da yer almaktadır (Bozkurt vd., 2012:232,233). Bu çalışmada misyon ve vizyon ifadelerinden yola çıkılarak Türk Bankacılık ve Finans sektöründeki bankaların girişimcilik özellikleri tespit edilmeye çalışılmıştır.

\section{GÍRIŞ̧iMCILIKK VE GİRIŞ̧iMCILİK ÖZELLIKLERİ}

Girișimcilikle ilgili literatür incelendiğinde girişimcinin tanımı ve sınıflandırılmasına ilişkin farklı yaklaşımlar olduğu görülecektir. Webster Sözlüğü girișimciyi (entrepreneur), kâr elde etmek üzere risk alarak kendi hesabına bir işletme kuran kişi olarak tanımlamaktadır. Kelime Fransızca'da "üstlenmek, taahhüt etmek" anlamına gelen entreprende kelimesinden türetilmiştir (Müftüoğlu ve Haliloğlu, 2013:1). Girişimci; mal ve hizmet üretimini gerçekleştirebilmek için riski üstlenerek doğal kaynak, sermaye, emek gibi üretim faktörlerini bir araya getirip faaliyete geçiren kişi olarak tanımlanmaktadır. Bir diğer ifade ile girişimci olmak için risk alarak mal ve hizmet üreterek pazarlamak üzere bir işletmeyi kurmak ve bu işletmede faaliyetleri yapmak gerekir (Tekin, 2004:3). Hisrich ve Peters (2002: 9-47) girișimciyi belirsizlik ortamında firsatları fark edip; gerekli kaynakları bir araya getirerek kâr elde etme ve büyüme amacı ile yeni bir iş kuran kişi; girişimciliği ise ekonomik, psikolojik ve sosyal riskler üstlenmeyi göze alıp zaman ve gayret harcayarak farklı bir değer yaratma süreci olarak tanımlamaktadır. Girișimcilik kavramı yıllardan beridir araștırmacılara konu olmaktadır; ancak herhangi bir kavram gibi değişmekte ve hızla gelişen ekonomi ve iş 
N. Kuduz- M. Atasever

İzmir Íktisat Dergisi / İzmir Journal of Economics

Yll/Year: 2022 Cilt/Vol:37 Sayl/No:1 Doi: 10.24988/ije.793444

çevresinde derin inceleme gerektirmektedir (Greblikaite \& Daugeliene, 2009:184). Girişimciliğe ilişkin bilimsel alanda girişimci ve girişimcilik kavramlarının birçok tanımı bulunmaktadır ve girişimcilik analizlerinde birçok farklı yaklaşım uygulanmıştır (Spilling \& Rosenberg, 2008:20). Girişimciliğin önemini kavrayan ekonomiler, başarılı girişimciler çıkarabilmek için girişimciliğin özelliklerini araştırma ve tanımlama yoluna giderek; girişimcilerin genel olarak sahip olduğu bazı ortak özellikler olduğundan bahsetmişlerdir (Rodermund, 2004: 499). Popp ve Holt (2013:11)' e göre girişimcilik çalışmaları "gelecekteki mal ve hizmetleri yaratmak üzere firsatların nasıl, kim tarafından, ne dereceye kadar keşfedildiği, değerlendirildiği ve işletildiğinin incelenmesi" olarak tanımlanmaktadır. Literatürde girişimci kavramını tanımlamanın iki temel yolu bulunmaktadır; birincisi girişimciyi gelişim potansiyeli ile birlikte küçük-orta-büyük bir kuruluşun kurucu veya sahip yöneticisi olarak tanımlarken diğeri girişimciyi sergilediği ekonomik işlev açısından tanımlamaktadır (Casson, 2010:141). Girişimciler toplumun genelinden çeşitli yollarla ayrılmaktadır. Güçlü bir başarma ihtiyacı duyarlar, risk alma davranışına daha eğilimlidirler ve insanların kaderlerini kendi ellerine alabileceklerine dair güçlü bir inançları vardır (Beugelsdijk \& Noorderhaven, 2004:200). Girişimcilik konusunda yapılan çalışmalarda girişimcilik özellikleri üzerinde önemle durulmuştur (Obschonka ve diğ., 2010: 63). Girişimciliğin bireysel özelliklerini ölçmede yaygın olarak kabul gören bir sınıflama beş faktör modeli olup; bu model kişiliği dışadönüklük, uzlaşmacılık, açıklık, vicdanlılık ve nevrotikliği içeren faktörler olarak tanımlamaktadır. Dışadönüklük; birinin sosyal, iddialı ve aktif olma eğilimini; uzlaşmacılık, birinin güvenilir, uyumlu ve fedakâr olma eğilimini; açıklık; birinin hayalperest, alışılmadık ve özgün olma eğilimini; vicdanlılık; birinin kusursuz, kendinden emin ve güvenilir olma eğilimini; nevrotiklik ise birinin endişeli, gergin ve güvensiz olma eğilimini göstermektedir (Holt, Rutherford, Clohessy., 2007:42-43). Girişimcinin bireysel özellikleri ve girişimci olmanın gereklilikleri ile aralarındaki uyum yaklaştıkça daha da başarılı olmaları muhtemeldir (Markman \& Baron, 2003:281). Girişimcilik özellikleri; sadece girișimcilerin davranışlarını yönlendirmemekte aynı zamanda işletmelerin örgütsel süreçleri, uygulamaları ve yönetsel faaliyetleri konusunda da etkili olmaktadır (Alam, 2011: 56). Literatürde farklı araştırmalar girişimciliğin farklı özellikleri üzerinde durmuştur. Liv d. (2006:342) girișimcilik eğilimini; araştırma-geliştirme, liderlik, inovasyon, risk ama ve rekabetçi olmak üzerindeki güçlü eğilimi belirterek ifade etmiştir. Foxall ve Minkes (1996:80)'in yaptığı çalışmada girişimcilerin paylaştıkları kişilik özellikleri incelenmiş; bilinçliliğin geniş kapsamı, yetki arayışı, bağımsızlık, üstünlük, özsaygı, motivasyonu başarma, kendine güven, sosyal beceri/empati, acelecilik, yenilik arayışı, sıkıntı eğilimi, sezgicilik, yaratıcılık, yenilik, fırsatçılık, proaktiflik, değişim temsilciliği, risk alma, cesurluk ve heyecan arayışı bu özellikler arasında dikkat çekmektedir. Girişimcilerle eşleşen özelliklere; başarma ihtiyacl, yenilikçilik, proaktif kişilik, genellenmiş özyeterlilik, strese hoşgörü, yetki ihtiyacı, içsel kontrol ve risk alma örnek gösterilebilir (Rauch \& Frese, 2007:358). Özel sektör işletmelerinde girişimcilik sürecine odaklanan çalışmalar çoğu zaman girişimciliğin risk alma, inovasyon, proaktiflik bölümlerinden yararlanmaktadır (Öztürk, 2012:151). Literatürdeki tüm araştırmalardan yola çıkarak girişimcilik kavramının benzer girişimcilik özellikleri etrafında birleştiği görülmektedir. Bunlar; risk alma, liderlik, yenilikçilik, yaratıcılık, güçlülük, proaktiflik, kendine güven, araştırma-geliştirme, başarı ve rekabetçiliktir. Risk Alma; girişimci için gerekli olan bir ön koşul olarak kabul edilmektedir. Girișimciye düşen görev; katlandığı riski avantaja dönüştürmek ve bundan fayda sağlamayı bilmektir (Macko ve Tyszka, 2000: 470). Yirminci yüzyıl görüşleri girişimciyi risk ve belirsizlik taşıyıcısı olarak görmektedir (Mason \& Harvey, 2013:1). Liderlik; Liderlik ve girişimcilik karşılıklı etkileşim içindedir. Girişimin başarısı liderlik becerilerine sahip olmaktan geçer. Buna karşı liderlik diğerlerinin takip edebileceği bir yol sunma yeteneğidir (Colbert, 2003: 30). Transformasyonel ve karizmatik liderlik teorileri liderlik ve girișimcilik arasında anlamlı bir ilişki olduğunu ileri sürmektedir (Eyal \& Kark, 2004:212). Yenilikçilik: Yenilikçilik, icat etmekten daha fazla bir şeydir. Fikirlerin ticarileştirilmesini, uygulanmasını ve mevcut ürünlerin sistemlerin, kaynakların modifikasyonunu da kapsamaktadır 
N. Kuduz- M. Atasever

İzmir Íktisat Dergisi / İzmir Journal of Economics

Yll/Year: 2022 Cilt/Vol:37 Sayl/No:1 Doi: 10.24988/ije.793444

(Bird, 1989: 39). Yenilikçilik açısından girişimcilik değişim ve yeniliğe dayanmaktadır (Ireland \& Webb, 2007:55). Yaratıcılık: Girişimcilik bir yaratıcılık biçimidir ve yeni kurulan işlerin faydalı ve orijinal olması sebebi ile girişimci yaratıcılık şeklinde de isimlendirilebilir (Lee vd., 2004:82). Yaratıcılık; girişimciliğin temel elemanıdır (Zampetakis ve Moustakis, 2006: 415). Güçlülük: Güçlü girişimcilerin uzun soluklu planlarda kayda değer sonuçlar elde ettikleri görülmüştür (Hayward ve diğ., 2006: 170). Başarılı girişimciler, kaynakları kullanma konusunda rakiplerine göre daha fazla kendine güvenmeli ve aldıkları kararların riskleri ile yaşayabilecek kadar güçlü ve iyimser olmalıdırlar (Casson, 2005: 361). Proaktiflik: Proaktif işletmeler yeni mal ve hizmet alanlarına girmede, teknolojileri ve yönetim tekniklerini kullanmada, rakipleri takip etmekten ziyade onlara öncü olma eğilimi gösterir (Covin ve Slevin, 1986: 631). Sadece pasif olarak tepki vermenin aksine çevreyi şekillendirme eğilimi olarak tanımlanmaktadır (Eyal \& Kark, 2004:213). Kendine güven, özellikle girişimcilik için stratejik karar alma ile ilgilidir. Bir örgüt bu özellik yardımıyla "kararlı" görülebilir ve bilinebilir (Erol ve Kanbur, 2014:153). Araştırma ve Geliştirme: Girişimciliğin tek başına büyümeyi sağlaması pek mümkün değildir; olumlu büyüme etkisi oluşturabilmesi, araştırma ve geliştirmeden faydalanmasına bağlıdır (Erken, 2008: 269). Araştırma-geliştirme alışılmışın dışında orijinal ve yararlı fikirler girişimciliğin yaşam kaynağıdır (Ward, 2004:174). Başarı: Johnson (1990: 39) yeni bir girişimin performansını belirleyen önemli unsurun bu başarma güdüsü olduğunu vurgulamaktadır. Başarı güdüsü ile girişimin performansı arasında anlamlı bir ilişki vardır (Collins ve diğ, 2004: 95). Rekabetçilik: Girişimcilik, cesur ve yenilikçi olmanın olumlu bir imajını akla getirmektedir ve araștırmacılar genellikle kurumsal girişimciliği rekabetçi avantajla pozitif yönde ilişkili olarak görmektedir (Teng, 2007:126; Zahra, 1996: 1713). Bu demektir ki rekabetçiliği geliştirmek, girişimcilikle mümkün iken girişimci olmakta rekabetçilikten geçmektedir. Girişimciliğin yükselmesi, rekabetçiliği geliştirmek için tasarlanan politikanın gerekli bir bileşenidir (Cuckovic ve Bartlett, 2007: 39).

Literatürde yer alan girișimcilik araștırmaları arasında farklılıklar olmasına rağmen işletmelerin sıklıkla tanımlanan girişimcilik özellikleri yukarıda bahsedildiği özellikleri içermektedir. Bireylerin girişimcilik özelliklerini gözlem ve kişisel ifadelerle tespit etmek nispeten kolay iken işletmeler için bu durum biraz daha zordur. İşletmelerin girişimci özelliklerinin yansımasını ise misyon ve vizyon ifadelerinde görmek mümkündür (Erol ve Kanbur, 2014: 153).

\section{MISYON VE VIZYON İFADESİ BILESSENLERI}

\subsection{Misyon İfadeleri}

Bir işletmenin varoluş nedeni olan misyon; işletmenin hangi sektörde, nasıl faaliyet yürüteceği, ne üreteceği, nerede pazarlayacağı, hangi pazarlama stratejilerinden yararlanacağı, nasıl bir imaj oluşturmak istediği gibi kendini tanıması ve varoluş nedenini işletme içinde / işletme dışında duyurması gibi faaliyetlerden oluşur ve strateji oluşturma çalışmalarında başlangıç noktasıdır (Ülgen ve Mirza, 2016: 68; Eken İnan, 2019:43). Misyon ifadesinin tanımına ilişkin literatür incelendiğinde yukarıda olduğu üzere genel olarak "bir işletmenin kim olduğu, ne yaptığı, amacının ne olduğu" ile ilgili yaklaşım mevcuttur (Bart ve Bontis, 2003: 361-393; Koçel, 2003:128). Türk Dil Kurumunda ise misyon; görev, amaç, dinsel, bilimsel veya diplomatik bir görev yüklenmiş kimselerden oluşan kurul anlamına gelmektedir (https://sozluk.gov.tr/). İşletmenin varoluş nedenini ifade eden misyon genellikle şu üç soruya yanıt vermektedir (Balkan ve Kahyaoğlu, 2018:494):

i. İşletme ne iş yapar?

ii. Kimlere hizmet vermektedir?

iii. Diğer işletmelerden farklılığı nedir?

Elbette bu soruları çoğaltmak mümkündür: Kendimizi nasıl tanımlıyoruz? Diğer işletmelerden farkımız ne? Kimlere hizmet vermek istiyoruz? Niçin varız? Ne yapmak istiyoruz? Asıl işimiz ne? Gibi işletmenin kendini tanımlamasına yardımcı olacak temel sorular da eklenebilir. 
N. Kuduz- M. Atasever

Izmir İktisat Dergisi / Izmir Journal of Economics

Yll/Year: 2022 Cilt/Vol:37 Sayl/No:1 Doi: 10.24988/ije.793444

Misyon; işletme çalışanlarına bir yön vermesi ve yapılan işi anlamlı hale getirmesi amacıyla belirlenmiş ve işletmeyi diğer işletmelerden ayırt etmeye yarayan ortak ve uzun dönemli bir görevdir (Dinçer, 2003: 10). İşletmenin varlık nedenini ortaya koyan misyon; işletmenin ne yaptığını, bunu yaparken amacının ne olduğunu, nereye gittiğinin, nasıl bir çevrede faaliyet gösterdiğini, sosyal ve ekonomik çevreyi pozitif yönde nasıl etkilediğini ve kendini nasıl gördüğünü belirtmektedir (Jacobsen, 2011: 15). Üst yönetimin birinci sorumluluğu olan "işimiz nedir?" sorusuna yanlış yanıt vermek "iş"te başarısızlığın en önemli nedeni olduğundan (Drucker, 2012:168); bir işletmenin faaliyet yürüttüğü çevrede kendisine atfettiği görevdir ve bu görevi hangi amaçla yapacağını, kendisini nasıl görmek istediğini anlatmak için bu kavramı kullanır (Güney, 2004: 169). İşletmenin misyonu oluşturulduktan sonra çok nadiren değiştirilmeli; ancak tabi ki yeniden gözden geçirilmelidir. Bir işletmenin misyonunda bir sözcük ya da ifadeyi değiştirmek sıra dışı bir durum olmasa da büyük çaplı değişiklikler nadiren görülür (Quigley, 1998: 56-57). Tüketiciler misyonlarını benimsedikleri ve paylaştıkları işletmelerden alışveriş yapmayı tercih ettikleri için misyon; tüm çalışanlara yön veren bir amaç olmalıdır, paylaşılan değerleri yansıtan bir ifade olmalıdır. Yani gerek tüketiciler gerek çalışanlar gerek de çevre tarafından paylaşılmalıdır (Ertuna, 2008: 90).

Misyon ifadelerinin günümüzde çok popüler olmasının ve en önemli yönetim araçlarından biri olarak kabul edilmesinin nedenlerinden biri, misyon ifadelerinin iç ve dış piyasalar üzerinde güçlü bir motivasyon etkisi oluşturduğuna ve misyon ifadesine sahip olmakla bundan pek çok fayda elde edilebileceğine olan inançtır (Coşkun ve Geyik, 2004: 287-288). Ülgen ve Mirze (2013:68,69)'ye göre etkili bir misyon açıklamasının tüketicilerin ve diğer sosyal paydaşların değer verdiği konuları da kapsaması gerekmektedir. Misyonun özellikleri şu şekilde özetlenebilir (Dinçer, 1996:97,98):

- Misyon; paylaşılan ortak değerler ve inançlardır

- Misyon; uzun solukludur, bazen işletmenin hayatı boyunca değişmeden kalır

- Misyon; ortadan kalkmaz ve ulaşılamaz

- Misyon; nicelikle ilgili değil nitelikle ilgili bir değerdir.

- Misyon; işletme içine değil dişına yönelik bir unsurdur.

- Her misyon işletmeye özel olmalıdır.

- Eren (2005:20)'ye göre belirlenen misyon ifadelerinin faydaları aşağıda belirtildiği şekildedir:

- İşletmede görev yapan tüm insan kaynağının benzer amacın gerçekleşmesi için bir arada bulunmasının sağlanması,

- Tüm örgütsel güçleri bir araya toplayarak; motivasyon sağlanması,

- İşletmenin akılcı kaynaklar bulmasına yardımcı olması ve stratejilerin belirlenerek bunların tahsisine yardımcı olması,

- İşletmenin tüm insan kaynağının iş sorumluluklarını kavramalarına yardımcı olması,

- Örgütsel amaçların ve stratejilerin belirlenmesini kolaylaştırması.

Bir işletmenin en gerekli yapısı olan misyon ifadesi; işletmenin gerçek ruhunu anlatmakta ve bilginin bileşimi olarak hizmet etmektedir (Moin, Ahsan, Khan, 2012: 103). Pearce ve David'in geliştirdiği misyon ifadeleri araştırmalarda sıklıkla tercih edilmektedir ve buna göre misyon ifadesi oluşturulurken işletmeye rehberlik eden sekiz anahtar ifadeyi içermektedir. Bunlar; müşteri ve Pazar hedeflerinin özelleştirilmesi, malların ve hizmetlerin ilkeleri, coğrafi olarak bölge, temel teknolojilerin kullanımı, gelişme, süreklilik ve kârlılık, felsefe, temel yetkinlik, kamu imajı ve çalışanlara değer verilmesi konusundaki bilgilere yer verilmesi gerektiğini belirtmektedir (1987:109). Literatürdeki çalışmalar incelendiğinde bu sekiz anahtar ifadeye ek olarak "çalışanlar" ifadesi eklenmiştir (Eken, 2019: 43). Misyon ifadeleri oluşturulurken hangi ögelerin kullanılacağı konusunda tam bir netlik yoktur. Kotler (1984)'e göre misyon ifadeleri oluşturulurken; işletmenin tarihi, yönetici ve sahiplerinin tercihleri, çevresel faktörler, mevcut kaynaklar ve özgün yeteneklerden oluşması gerekmektedir (Köseoğlu, 2003: 91). Want ise işletme hedeflerinin ilkeleri, ortak kimlik, işletme politikaları ve ortak değerlerin yer alması gerektiğini ifade etmektedir (Want, 1986:46-47). Bart 
N. Kuduz- M. Atasever

Izmir İktisat Dergisi / Izmir Journal of Economics

Yll/Year: 2022 Cilt/Vol:37 Sayl/No:1 Doi: 10.24988/ije.793444

(2007:686) ise misyon ifadeleri içeriğine ilişkin yapmış olduğu çalışmada amaç cümlesi, değerler/inançlar cümlesi, özel müssterilere hizmet, eşsiz kimlik, müssteri tatminine değinme, rekabet/güç farklılığı, mal/hizmet teklifi, açık bir rekabet hedefi, istenilen kamu imajı, işgörenlere ilgi, özel davranış standartları, topluma ilişskin ögeler, vizyon cümlesi, istenilen rekabet pozisyonu, özel finansal olmayan hedefler, genel işletme düzeyi amaçlar, paydaşlara iliş̧in ögeler, iş bölgesi, rekabet stratejisi, özel finansal hedefler, teknoloji tanımı, tedarikçilere ilisskin ögeler, sürekliliğe ilișkin ögeler kullanılması gerektiğini belirtmektedir.

\subsection{Vizyon İfadeleri}

Bir işletmenin gelecekte olmasını arzuladıkları durumun ifadesi olan vizyon (Ülgen ve Mirze, 2016:69); gelecekte arzu edilen yerin belirlenmesi, aynı zamanda işletmelerin devamlılığını sağlayacak stratejiler olușturma konusunda da rehber rol oynayacaktır. İșletmelerin faaliyet gösterdikleri sektörlerden, müşteri profiline, çalışan profilinden, işletme felsefesine kadar farklılıklar olduğundan stratejik planlamalarında da farklılıklar olacaktır. Bu bağlamda vizyon ifadeleri işletmeden işletmeye farklılık göstermektedir ve vizyon ifadelerinin hazırlanmasında aşağıdaki noktalara dikkat edilmelidir (Henry, 2008:11): Kolay anlaşllabilir olmalı, Kolay hatırlanabilir olmalı, Pozitif olmalı, Motive edici olmalı, Hayal gücünü yansıtmalı, Çekici olmalı, Meydan okumalı, Geleceğe yönelik olmalıdır.

Vizyona sahip olan işletmelerin vizyonu olmayan işletmelere kıyasla daha başarılı olduğu araştırmalarda ortaya konulmuştur. İşletmelere yön veren ve işletmenin amaçlarına ulaşılmasında yöneticilere motivasyon sağlayan vizyonun ișe yaraması işletmedeki tüm çalışanların bu vizyonu paylaşmasına bağlı olmaktadır (Dinçer, 2003: 14-15). Bir işletmenin konumunun her şeyden önemli olan amacı şeklinde ifade edilen vizyon ifadesi; "ne olmak istiyoruz?" gibi soruları tanımlamayı amaçlamaktadır ve işletmenin gittiği yön, sahiplenmeye niyetlendiği iş konumu ve gelişmek üzere planladığı yetenekleridir (Karabulut, 2007:28). İleri görüşlülük olarak da tanımlanabilen vizyon; geleceğin hayal edilmesini, nasıl bir işletme olunacağına ilişkin düşünceleri yansıtır; vizyona sahip olan bir işletme geleceği planlar ve gelecekteki konumunu belirler (Aktaran: Oruç ve Zengin, 2015: 36). Stratejik yönetimin en önemli parçalarından biri olan vizyon; işletmenin misyonu, amaçları ve hedefleri ile değerlerinin bir bileşkesidir (Mirze ve Ülgen, 2007: 183).

Bir misyon ifadesi yazmadan önce işletmedeki liderler gelecek için neyin mevcut olduğu konusunda bir fikre sahip olmalıdır ki bu, misyon ifadesinin de temelidir. Başka bir deyişle vizyon; misyon ve ilgili amaçlar için sıçrama tahtası olan stratejik bir yön göstericidir (Darbi, 2012:95). Laurel (2012)'ye göre vizyon bir işletmenin gelecekte kendisini nerede görmek istediğinin betimsel anlatımıdır ve gelecekte sahip olunmak istenen yere vurgu yaptığından dolayı da vizyon aslında işletmelerin ilham kaynağıdır (Aktaran: Aytar ve Soylu, 2017:120). Collins ve Porras (1996)'a göre vizyon iki temel unsurdan oluşmaktadır. Birincisi temel ideoloji olup işletmenin neyi temsil ettiği ve neden var olduğunu açıklar. Temel ideoloji; temel değerler ve esas amaç etrafında şekillenmektedir. Temel ideoloji; “... Biz kimiz? Neden varız? Neyi temsil ediyoruz?” sorularının cevabıdır. Zor zamanlarda yol göstererek başarıya ulaşmada yardımcı olurlar. İkinci temel unsur vizyonlaştırılmış gelecek olup; işletmenin ne olmak istediği, neyi başarmaya kararlı olduğu, uzun vadede neye yöneldiğidir. Ulaşılamayacak kadar yüksek ya da çok kolay da başarılacak kadar alt seviyede olmamalıdır. Aksi halde güdüleme ve yönlendirme özelliğini yitirir (Aktaran: Balkan ve Kahyaoğlu, 2018: 495,496).

Vizyon; bir tahmin ya da bir düş değil bilakis gelecek için bir tutumdur ve işletmenin gelecekte nasıl olacağına dair somut bir ifadedir (Akgemci, 2007:21). Literatürde misyon ve vizyon kavramları birbirine bağlı ve iç içe geçmiş olsa da vizyon ifadeleri bir işletmenin arzuladığı gelecek görüntüsünü açılarken; misyon ifadeleri ișletmenin var oluş amacını ifade etmektedir. Vizyon ifadeleri işletmelerin temel ideolojilerini ve hayali gelecek görüntüsünü yansıtmaktadır. Temel ideolojiler kapsamında işletmenin özellikleri ve özgün kimliğini yansıtan vizyon ifadeleri, hayali bir gelecek 
görüntüsü kapsamında işletmenin günümüzden 10 ile 30 yıl sonrasına kadar olmak istediği durum hakkında bilgi vermektedir (Tanković, 2013: 332). Vizyon; gelecekte yaratılmak istenen durumun zihinsel bir ifadesi ve işletmenin ulaşmak istediği bugünkü durumdan daha iyi, daha başarılı, gerçekçi, güvenilir ve çekici geleceğidir (Awamleh ve Gardner, 1999:346). Vizyon ifadeleri ile gelecekte yapılacak faaliyetlerin yöneticinin bakış açısına bağlı olarak ifade edilmesi, stratejik yönetim sürecinin başarısına katkı sağlamaktadır (Eren, 2005:18). Tüm çalışanlar tarafından yanıtlanması gereken "ne yaratmak istiyoruz" sorusunun yanıtı olan vizyon (Gürüz ve Gürel, 2009:34); işletme performansı, işletme hedefleri ve işletme standartlarını daha üst noktalara taşıyacak bir yapıda olmalıdır (Kılıç, 2010:89). Başarılı işletmelerin ortak noktası, stratejilerini değişen iç ve dış çevre şartlarına adapte edebilmelerinin yanı sıra, belirli bir vizyon, amaç ve hedefe sahip olmalarıdır. Bireylerin, toplumların, işletmelerin ve ülkelerin başarı hikayelerine göz atıldığında hepsinin vizyon sahibi olduğuna dikkat çekilmektedir (Ülgen ve Mirze, 2007: 179). Bazı yazarlara göre (David 2005; Hamel ve Prahalad 1994) öncelikle vizyonun oluşması ve misyon dahil diğer süreçlerin vizyonu temel alması gereği üzerinde dururken; diğer bazı yazarlar ise (Bryson and Alston 1996; J.C. Corris ve Porras 1996) misyonun önce belirleneceği, vizyonun ve diğer stratejik süreçlerin buna göre oluşacağını ileri sürmektedir. Ancak vizyonun "nereye gitmek istiyoruz" sorusuna cevap oluşturması ve misyonun da oraya ulaşmak için "şimdi nelerin, nasıl yapılması gerektiği” ile ilgili olduğu konusunda bazı küçük farklılıklar dışında bir uzlaşma sağlanmıştır denilebilir (Aktaran: Kılıç, 2010: 93). Vizyonun geleceğe yönelim, özlülük, açıklık, kararlılık, arzu edilebilirlik, ilham verme yeteneği unsurları çalışanlarda istek uyandırmayı beraberinde getirmektedir (Kukkurainen, 2012: 869). Gill (2013:312)'ye göre vizyon şevk verici, ahlaklı ve anlamlı olmalıdır. Tüm bunlar dikkate alındığında George (1997:66)’ya göre işletme bünyesinde paylaşılan vizyon ifadelerinin faydaları aşağıda belirtilmiştir:

İşletme menfaatleri tüm çalışanlar tarafından benimsenmektedir, faaliyetleri kolaylaştırmaktadır, faaliyetlerin birbirleriyle karşılaştırılmalarına olanak sunmaktadır, işletmelerin değişim ve dönüşümlerinin etkinliği için daha fazla faaliyetlere odaklanmaktadır.

\section{DEĞERLER}

Sözlük anlamıyla değer; nesne ve olayların bir insan, bir sınıf ya da bir toplum tarafından taşıdı̆̆ı önemi belirleyen niteliği ya da toplumca kabul edilen doğaüstü, simgesel veya maddi olabilen amaç; kısaca neyin doğru, saygıdeğer ve istenen olduğuna dair geniş, soyut ve ortak ölçülerdir (Güney, 2004: 57). Bireyler tarafından içselleştirilmiş, paylaşılan grup normları olan değerler (Czinkota, Ronkainen ve Moffett, 2009); işletmelerin sahip oldukları geleneklerin içerisinde bulunan inançlar ve ahlak ilkeleri olarak ifade edilmektedir (Clayton, 2002: 305-329). Yeni durumlar meydana geldiğinde karar vericileri yönlendiren işletme inançlarının ifadesi olan değerler (Deliz, 1997:171); işletme içindeki kurallar ve davranış standartlarına anlam kazandırırlar (Yurtseven, 1988: 26). Değerler benimsenip kabul edildikten sonra kişilik ve işletme kültürü üzerinde belirleyici bir rol oynayarak; öncelik vermede ve karar vermede ölçüt olarak işlev görürler. Hayvanlar için içgüdü ne ise insan için de değer odur (Hultman, 2005:33). Hodgkinson (2008:142)'ye göre değerlerin en önemli fonksiyonu; çeşitli durumlardaki davranışlara rehberlik eden, kişiye özgü standartlar sağlamalarıdır. Çalışanların kurumu içselleştirdiğinin başlıca göstergesi olan değerler; kurum kültürünün de temelini oluşturmaktadır. Kurum değerlerinin paylaşılması, çalışanların hedefleriyle uyumunun sağlanması gerekmektedir. Dolayısıyla kurum değerlerinin diğer bir işlevi de hedeflere yönlendirmek ve bir konuya odaklanmış kurum sinerjisini oluşturmaktır. Kurum değerlerinin oluşturulmasında şu sorulara cevap aranmalıdır (Kılıç, 2010:84): Temel inançlarımız nedir?, Ahlaki kurallarımız nedir?, Davranış kurallarımız nedir?, Özen gösterdiğimiz amaçlar nedir?, İdeallerimiz nedir?, Aldığımız kararların doğru veya yanlış olduğuna nasıl karar veririz?, Yaptığımız davranışların doğru veya yanlış olduğuna nasıl karar veririz?, Hangi kıstasları ele alırız? 
(Wiener, 1988)'e göre bireysel değerler; kişinin amaçlarına ve eylemlerine rehberlik ederken; örgütsel değerler örgütsel amaç, politika ve stratejilere yol göstermektedir (Aktaran: Üstün ve Tatlı, 2018:21). Bu bağlamda işletmelerde değerlerin gücünden olumlu şekilde yararlanabilmek, bireysel ve örgütsel değerler arasında uyum sağlanması ile mümkün olacaktır (Posner ve Schmidt, 1992: 8182).

Milton Rokeach (1973)'e göre değerler iki grupta incelenebilirler (Hultman, 2005:33):

i. Nihai (Terminal) değerler, çok yoğun bir şekilde arzulanan son durumdur; mesela maddi rahatlık, özgürlük, başarma duygusu vb... Bireyin hayatı boyunca başarmak istediği amaçlardır ve iki parçası bulunmaktadır: Amaçlarımız ve kişisel misyonumuz neden var olduğumuzu; gelecek için hayallerimiz veya kişisel vizyonumuz ise ne olmak istediğimizi tanımlar. Amaç değerler bizi idealize edilmiş öz-imajımıza, hayallerimize doğru yönlendirir.

ii. Araçsal (Instrumental) değerler, amaç değerleri ya da hayallerimizi nasıl gerçekleştireceğimizi tanımlarlar. Örneğin; dürüstlük, çalışkan olmak, açık fikirli olmak vb... İnsanlar "değer" terimini kullandıklarında genellikle araçsal değerleri kastederler.

Literatür incelendiğinde işletmelerin değerler üzerinde çok fazla durdukları gözlenmektedir. Genellikle bu işletmeler üç temel özelliği paylaşırlar. Birincisi; işlerini nassl yapmayı hedefledikleri konusunda açık ve net bir felsefeleri vardır. İkincisi; yönetimlerini şekillendirmek ve çevre ile ilişkilerinde uyumlu hale getirdikleri örgütsel değer kavramlarına çok önem vermişlerdir. Üçüncü ve son olarak da bu değerler başarılı işletmelerin en üst kademesinden en alt kademesine kadar benimsenmiş ve paylaşılmışlardır (Kılıç, 2010: 87). Değerler hakkında açık bir anlayış ve inanç olmadan misyon ve vizyon da basit birer kopyadan ibarettir. Dolayısıyla işletme misyon ve vizyonu aşağıdaki gibi formüle edilmektedir (Aktaran: Kılıç, 2010:86):
Örgütsel İdeal +
Değerler $=$ Vizyon
Örgütsel Hedef $\quad+$
Değerler = Misyon

\section{ARAŞTIRMA METODOLOJISİ}

Çalışmanın bu bölümünde araştırmanın amacı, araştırmanın önemi, araştırmanın yöntemi ve araștırmanın bulguları yer almaktadır.

\subsection{Araştırmanın Amacı, Kapsamı, Önemi ve Kısıtları}

Bu çalışmanın amacı teorik bölümde bahsedilen çerçeveye dayanarak 2020 Ağustos ayı itibariyle bankacılık ve finans sektöründe yer alan 34 girişimcinin, girişimcilik özelliklerini web sitelerinde yer alan misyon ve vizyon ifadelerini olușturan unsurlara göre incelemek, girișimciliği ne düzeyde yansıttığını belirlemektir. Dolayısıyla web sitesinde paylaşmadığı halde başka platformlarda misyon ve vizyon ifadesi paylaşan banka ve finans işletmelerini kapsamamaktadır. Daha geniş perspektiften ise finans işletmelerinin girişimcilik özelliklerinin ortaya konmasıdır. Böylece misyon ve vizyon ifadeleri oluşturulurken girişimcilik özelliklerinin yansıtılmasında kullanılan karışıklıklara açıklık getirmesi bakımından ve literatürde girişimcilik özellikleri ile misyon ve vizyon ifadeleri ilişkisi bankacılık ve finans sektörü açısından incelenmediğinden önem ve özgünlük taşıdığını ifade etmek mümkündür.

\subsection{Araştırmanın Yöntemi}

$\mathrm{Bu}$ araştırmanın yöntemi olarak nitel araştırma tekniği kullanılmıştır. Bu çerçevede Türkiye'de faaliyet gösteren tüm banka ve finans işletmeleri evreninde banka işletmeleri örneklem olarak seçilmiştir. Araştırma amaçları doğrultusunda Türkiye'de faaliyet gösteren banka ve finans işletmelerinin web sayfaları yardımı ile misyon vizyon, örgütsel değere ilişkin elde edilen ifadelerden misyon ve vizyon ifadeleri nitel içerik analizi yardımı ile incelenmiştir. $\mathrm{Bu}$ yöntemde yorum yapılırken; mesajı gönderen, mesajın kendisi ve mesajın alıcısı dikkate alınmaktadır ve her metinde yoruma ve tanımlanmaya değer mesajlar bulunmaktadır (Weber, 1990:5; Graneheim ve Lundman, 
2004). İçerik analizi; (Qualitive Content Analysis: QCA) yöntem olarak mevcut olan metinlerin nicel ve nitel boyutlarından hareket ederek mevcut olmayan yeni bilinmeyen sosyal gerçeğin bazı boyut ve kesitlerine yönelik birtakım bulguları elde etmeyi amaçlayan bir yöntemdir. İletişimin içeriklerinde gözlenen sonuçlardan doğrudan gözlenmeyen etkenlere yönelik sonuç çıarılmaya çalışılır (Gökçe,2006: 20). İçerik analizi, "dikkatli, ayrıntılı ve sistematik bir incelemedir ve örnekleri, konuları, önyargıları ve anlamları tanımlama çabası içinde bir materyalin belirli bir bölümünü anlamlandırmadır", "geniş miktarlarda verinin azaltılmasına izin veren kodlama ekipleri ile ölçümdür" ve "içerik analizinde sonuçlar önceden seçilerek sınıflandırılmış belirli değişkenlerle ilgili sıklık miktarlarıdır" (Peetz \& Reams, 2011:211). Bankaların misyon ve vizyon ifadelerindeki gizli ve açık içerikler analiz edilmeye çalışılarak; bankaların misyon ve vizyon ifadeleri teorik çerçevede belirlenmiş olan girişimcilik özellikleri boyutunda değerlendirmeye tabi tutulmuştur. Bu boyutlar; risk alma, liderlik, yenilikçilik, yaratıcılık, güçlülük, proaktiflik, araştırma ve geliştirme, başarı ve rekabetçiliktir. Her bir bankanın misyon ve vizyon ifadelerinin girişimcilik özellikleriyle ilgili boyutunu değerlendirmek için bir kodlama yöntemi kullanılmıştır. Araştırmada veri toplama tekniği olarak ikincil veri toplama tekniğinden yararlanılmıştır. Örneklemde yer alan bankaların web sayfalarında paylaştıkları misyon ve vizyon ifadelerine ulaşılarak içerik analizi gerçekleştirilmiştir. Misyon ve vizyon ifadelerinde girişimcilik özellikleri var ise + yok ise - kodlama yapılarak incelenmiş; sonuçlar yorum şeklinde aktarılmıştır.

\subsection{Araștırmanın Bulguları}

Bu çalışmada banka işletmelerinin girişimcilik özellikleri literatürde belirlenen boyutlar ölçüsünce değerlendirmeye tabi tutulmuștur. Misyon ve vizyon ifadeleri bir ișletmenin davranıșsal rolünün aynası durumundadır. Bu bağlamda teorik çerçevede açıklanan girişimcilik özellikleri misyon ve vizyon ifadelerine bağlı olarak Türkiye'de faaliyet gösteren banka işletmelerinin girişimcilik özelliklerini değerlendirmek üzere kullanılmıștır. Bu bağlamda Türk Bankacılık Sektörü'nde yer alan bankaların TBB nezdinde yapılmış olan sınıflaması baz alınmış; bu sınıflama doğrultusunda ilgili bankaların misyon ve vizyon ifadesi bileșenlerine bağlı olarak girişimcilik özelliklerinin ortaya konması amacıyla elde edilen bulgular değerlendirilmiştir. Türk Bankacılık Sektörü için yapılan gruplar incelendiğinde 30 Ağustos 2020 tarihi itibariyle gruplar aşağıda görüldüğü gibidir (Türkiye Bankaları Birliği, 2020):

A. MEVDUAT BANKALARI

1. KAMUSAL SERMAYELİ MEVDUAT BANKALARI

i. TÜRKIYE CUMHURIYETI ZİRAAT BANKASI A.Ş.

ii.TÜRKIYE HALK BANKASI A.Ş.

iii.TÜRKIYE VAKIFLAR BANKASI T.A.O.

2. ÖZEL SERMAYELI MEVDUAT BANKALARI

i. ADABANK A.Ş.

ii.AKBANK T.A.Ş.

iii.ANADOLUBANK A.Ş.

iv.FIBBABANKA A.Ş.

v.ŞEKERBANK T.A.Ş.

vi.TURKISHBANK A.Ş.

vii.TÜRK EKONOMİ BANKASI A.Ş.

viii.TÜRKIYE İŞ BANKASI A.Ş.

ix.YAPI VE KREDİ BANKASI A.Ş.

3. TASARRUF MEVDUATI SİGORTA FONUNA DEVREDILLEN BANKALAR

i.BİRLEŞİK FON BANKASI A.Ş.

4. YABANCI SERMAYELİ BANKALAR

i.TÜRKIYE'DE KURULMUŞ YABANCI SERMAYELİ BANKALAR

a.ALTERNATIFBANK A.Ş.

b.ARAP TÜRK BANKASI A.Ş.

c. BANK OF CHINE TURKEY A.Ş. 
d.BURGAN BANK A.Ș.

e.CITIBANK A.Ș.

f. DENIZBANK A.Ş.

g.DEUTSCHE BANK A.Ş.

h.HSBC BANK A.Ş.

i. ICBC TURKEY BANK A.Ş.

j. ING BANK A.Ş

k.MUFG BANK A.Ş.

l. ODEA BANK A.Ş.

m.QNB FINANSBANK A.Ş.

n.RABOBANK A.Ş.

o.TURKLAND BANK A.Ş.

p.TÜRKIYE GARANTİ BANKASI A.Ş.

ii. TÜRKIYE'DE ŞUBE AÇAN YABANCI SERMAYELİ BANKALAR

a.BANK MELLAT

b.HABİB BANK LIMITED

c.INTESA SANPAOLO A.P.A.

d.JPMORGAN CHASE BANK N.A.

e.SOCIÉTÉ GÉNÉRALE (SA)

5. KALKINMA VE YATIRIM BANKALARI

i. KAMUSAL SERMAYELI KALKINMA VE YATIRIM BANKALARI

a.İLLER BANKASI A.Ş.

b.TURK EXIMBANK

c.TÜRKIYE KALKINMA VE YATIRIM BANKASI A.Ş.

ii. ÖZEL SERMAYELİ AKLKINMA VE YATIRIM BANKALARI

a.AKTIF YATIRIM BANKASI A.S

b.DILER YATIRIM BANKASI A.Ş.

c.GOLDEN GLOBAL YATIRIM BANKASI A.Ş.

d.GSD YATIRIM BANKASI A.Ș.

e.ISTANBUL TAKAS VE SAKLAMA BANKASI A.Ș.

f. NUROL YATIRIM BANKASI A.Ş.

g.TÜRKIYE SINAİ KALKINMA BANKASI A.Ş.

iii. YABANCI SERMAYELİ AKTILIM BANKALARI

a.BANKPOZITİF KREDİ VE KALKINMA BANKASI A.Ş.

b.MERRILL LYNCH YATIRIM BANK A.Ş.

c.PASHA YATIRIM BANKASI A.Ş.

d.STANDART CHARTERED YATIRIM BANKASI TÜRK A.Ş.

Tablo 1. Kamusal Sermayeli Mevduat Bankalarının Misyon ve Vizyon İfadeleri

\begin{tabular}{|c|c|c|}
\hline BANKA & MİSYON & VİZYON \\
\hline $\begin{array}{l}\text { T.C. } \\
\text { ZIRAAT } \\
\text { BANKASI } \\
\text { A.Ş. }\end{array}$ & $\begin{array}{l}\text { Müşteri ihtiyaç ve beklentilerini en iyi şekilde anlayarak, } \\
\text { onlara en doğru kanaldan en uygun çözüm ve değer önerilerini } \\
\text { sunan, yaygın şube ağı ve alternatif dağıtım kanalları ile geniş } \\
\text { ürün ve hizmet yelpazesini toplumun her kesimine en hılı } \\
\text { en etkin şekilde ulaştıran, etik değerlerinin ve sosyal } \\
\text { sorumluluğunun bilincinde olarak dünya standartlarında } \\
\text { sürdürülebilir kârlılık ve verimlilikle faaliyet gösteren, } \\
\text { müșteri memnuniyetini her șeyden üstün tutan bir banka } \\
\text { olmaktır. (www.ziraatbank.com.tr) }\end{array}$ & $\begin{array}{l}\text { Türkiye'de ve dünyanın her yerinde yaygın, } \\
\text { güvenilir ve aynı kalitede hizmet sunan, herkesin } \\
\text { ve her kesimin bankası olan, müşteri ve insan } \\
\text { kaynağını en değerli aktifi olarak kabul eden, köklü } \\
\text { geçmişine yakışır şekilde sürekli olarak fark ve } \\
\text { değer yaratan, rakiplerinin örnek aldığı, her } \\
\text { aşamada bir bankadan daha fazlasını vaat eden, } \\
\text { evrensel, saygın ve piyasa değeri yüksek, lider } \\
\text { banka olmaktır. (www.ziraatbank.com.tr) }\end{array}$ \\
\hline $\begin{array}{l}\text { TÜRKIYE } \\
\text { HALK } \\
\text { BANKASI } \\
\text { A.Ş. }\end{array}$ & $\begin{array}{l}\text { Üstlendiği sosyal sorumluluk ve yüksek görev bilinci } \\
\text { içerisinde, tüm bankacılık hizmetlerini etkin şekilde yerine } \\
\text { getirerek, müşterilerine, hissedarlarına ve çalışanlarına } \\
\text { sürekli katma değer yaratmak; bankacılık sektörünün ve } \\
\text { sermaye piyasalarının gelişimine katkıda bulunmak; } \\
\text { bölgemizde ve dünya bankacılığında saygın bir yer edinmek. } \\
\text { (www.halkbank.com.tr) }\end{array}$ & $\begin{array}{l}\text { Evrensel bankacılığın tüm gereklerini yerine } \\
\text { getiren, bireysel hizmetlerde güçlü, bölgenin lider } \\
\text { KOBİ bankası olmak. (www.halkbank.com.tr) }\end{array}$ \\
\hline $\begin{array}{l}\text { TÜRKIYE } \\
\text { VAKIFLAR } \\
\text { BANKASI } \\
\text { T.A.O. }\end{array}$ & $\begin{array}{l}\text { Vakıf kültüründen aldığı güçle; kendisine emanet edilen varlık } \\
\text { ve değerleri etkin ve verimli yöneterek müşterilerine, } \\
\text { çalışanlarına, hissedarlarına ve topluma kattığı değerleri } \\
\text { sürekli artırmak.(www.vakifbank.com.tr) }\end{array}$ & 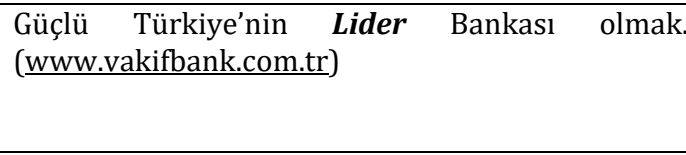 \\
\hline
\end{tabular}


Tablo 1'de görüldüğü üzere kamusal sermayeli mevduat bankalar olan T.C. Ziraat Bankası A.Ş., Türkiye Halk Bankası A.Ş., Türkiye Vakıflar Bankası T.A.O'nun misyon ve vizyon ifadeleri bulunmaktadır. Bunlardan T.C. Ziraat Bankası A.Ş.'nin misyon ve vizyon ifadeleri incelendiğinde misyon ifadesinde literatürde yer alan girişimcilik boyutlarından herhangi birine rastlanmamıştır; vizyon ifadesinde ise girişimcilik özellikleri boyutlarından olan rekabetçilik ve liderlik ifadeleri yer almaktadır. Buradan yola çıkarak T.C. Ziraat Bankası A.Ş.'nin girişimcilik özelliklerinden rekabetçiliğe ve liderliğe odaklandığını söylemek mümkündür. Türkiye Halk Bankası A.Ş.'nin misyon ve vizyon ifadeleri incelendiğinde misyon ifadesinde yine girişimcilik özellikleri boyutlarına rastlanamazken; vizyon ifadesinde lider olma boyutuna vurgu yapılmıștır. Türkiye Vakıflar Bankası T.A.O.'nun misyon ifadesinde de diğer iki kamusal sermayeli mevduat bankasında olduğu gibi girişimcilik boyutlarına rastlanmazken; vizyon ifadesinde lider olma boyutuna vurgu yapılmıştır. Tüm bu bulgulardan hareketle kamusal sermayeli mevduat bankalarının misyon ifadelerinde girişimcilik boyutlarına rastlanmazken; vizyon ifadelerinde bu üç bankanın da liderlik boyutuna odaklandıkları görülmektedir şeklinde yorumlanabilir.

Tablo 2. Özel Sermayeli Mevduat Bankalarının Misyon ve Vizyon İfadeleri

\begin{tabular}{|c|c|c|}
\hline BANKA & MISYON & VİZYON \\
\hline ADABANK A.Ş. & $\begin{array}{l}\text { Web sitesinde paylaşılmış bir misyon ifadesi } \\
\text { bulunmamaktadır. (www.adabank.com.tr) }\end{array}$ & $\begin{array}{l}\text { Web sitesinde paylaşılmış bir vizyon } \\
\text { bildirisi bulunmamaktadır. } \\
\text { (www.adabank.com.tr) }\end{array}$ \\
\hline AKBANK T.A.Ş. & $\begin{array}{l}\text { Yenilikçi finansal çözümlerimiz ve güvenilirliğimiz ile } \\
\text { tüm paydaşlarımız için kalıcı ve yüksek değer } \\
\text { yaratmak. } \\
\text { (www.akbank.com.tr) }\end{array}$ & $\begin{array}{l}\text { Türkiye'yi geleceğe taşıyan öncü banka } \\
\text { olmak. } \\
\text { (www.akbank.com.tr) }\end{array}$ \\
\hline $\begin{array}{l}\text { ANADOLUBANK } \\
\text { A.Ş. }\end{array}$ & $\begin{array}{l}\text { Müșterileri, çalıșanları, pay sahipleri ve topluma } \\
\text { optimum bileşim içerisinde değer yaratmak. } \\
\text { (www.anadolubank.com.tr) }\end{array}$ & $\begin{array}{l}\text { Türkiye sathında reel ekonomik faaliyet } \\
\text { yaratan aktörlerin vazgeçilmez finans } \\
\text { ortağı olmak. } \\
\text { (www.anadolubank.com.tr) }\end{array}$ \\
\hline FİBABANKA A.Ş. & $\begin{array}{l}\text { İnsanların hayatını kolaylaștıracak en hızlı bankacılık } \\
\text { hizmetini sunmak. } \\
\text { (www.fibabanka.com.tr) }\end{array}$ & $\begin{array}{l}\text { Türkiye'nin en sevilen bankası olmak. } \\
\text { (www.fibabanka.com.tr) }\end{array}$ \\
\hline $\begin{array}{l}\text { ŞEKERBANK } \\
\text { T.A.Ş. }\end{array}$ & $\begin{array}{l}\text { Misyonumuz; Anadolu bankacılığı anlayışıyla köyden } \\
\text { kente; yerel özellikleri ve ihtiyaçları dikkate alan, } \\
\text { bankası olmayanları da bankacılık hizmetleriyle } \\
\text { tanıştıran, mutlu müşteri, çalışan ve ortaklarıyla } \\
\text { değer yaratarak birlikte büyüyen, gücünü köklü } \\
\text { geçmişinden alan, çağdaş bir bankayız. } \\
\text { (www.sekerbank.com.tr) }\end{array}$ & $\begin{array}{l}\text { Vizyonumuz; Türkiye'de, aktif } \\
\text { büyüklükte ilk on özel banka arasında, } \\
\text { "küçük işletmelerin finansmanında } \\
\text { lider banka" olarak yer almak. } \\
\text { (www.sekerbank.com.tr) }\end{array}$ \\
\hline $\begin{array}{l}\text { TURKISH BANK } \\
\text { A.Ş. }\end{array}$ & $\begin{array}{l}\text { Tarihsel değerlerimizden ödün vermeden, etik } \\
\text { bankacılık ilkelerine bağlı kalarak, yenilikçi, } \\
\text { sağduyulu, kaliteli ve hızlı hizmet anlayışımızla } \\
\text { müşterilerimize, çalışanlarımıza, hissedarlarımıza ve } \\
\text { topluma sürdürülebilir değer yaratmaktadır. } \\
\text { (www.turkishbank.com.tr) }\end{array}$ & $\begin{array}{l}\text { Köklü geçmişine yakışır şekilde sürekli } \\
\text { olarak paydaşları için fark ve değer } \\
\text { yaratan, rakiplerinin örnek aldığı, her } \\
\text { aşamada bir bankadan daha fazlasını } \\
\text { vaat eden, evrensel, saygın ve itibarlı } \\
\text { ihtisas bankası olmaktır. } \\
\text { (www.turkishbank.com.tr) }\end{array}$ \\
\hline $\begin{array}{l}\text { TÜRK EKONOMİ } \\
\text { BANKASI A.Ș. }\end{array}$ & $\begin{array}{l}\text { TEB hizmet mükemmeliyetine ve müşterilerine } \\
\text { kendini adamış, tüm paydaşlarına aynı şeffaflık ile } \\
\text { yaklaşan, işini tutkuyla icra eden, tüm riskleri izleyen } \\
\text { ve yöneten, disiplinli, bilgi ve analize dayanan } \\
\text { objektif bir kredi kültürüne sahip, hizmete } \\
\text { odaklanmış, sürekli kendisini yenileyen profesyonel } \\
\text { bir kadro ile dünya standartları üzerinde teknolojik } \\
\text { bir altyapıyı barındıran, sürdürülebilir ve karlı }\end{array}$ & $\begin{array}{l}\text { Orta ölçekli bankalar arasında lider } \\
\text { olmak ve yenilikçi müşterilerine kaliteli } \\
\text { hizmet, hissedarlarına ise sürdürülebilir } \\
\text { kar yaratmaktır. TEB'in hem müşterileri } \\
\text { hem de çalışanları için Türkiye'nin en } \\
\text { yenilikçi ve en pratik bankası olması } \\
\text { öngörülmektedir. (www.teb.com.tr) }\end{array}$ \\
\hline
\end{tabular}




\begin{tabular}{|c|c|c|}
\hline & $\begin{array}{l}\text { büyümeye odaklı bir banka olarak hizmet vermeyi } \\
\text { planlamaktadır (www.teb.com.tr). }\end{array}$ & \\
\hline $\begin{array}{ll}\text { TÜRKIYE } & \text { IŞ } \\
\text { BANKASI A.Ş. } & \end{array}$ & $\begin{array}{l}\text { WEB sitesinde Misyon bilgisi yoktur; stratejik yerine } \\
\text { amaçlar bilgisi verilmiştir } \\
\text { (www.isbank.com.tr). }\end{array}$ & $\begin{array}{l}\text { Kapsayıcı ve katılımcı bir yaklaşımla } \\
\text { sürdürülebilir değer yaratan geleceğin } \\
\text { bankası olmak. } \\
\text { (www.isbank.com.tr). }\end{array}$ \\
\hline $\begin{array}{l}\text { YAPI VE KREDİ } \\
\text { BANKASI A.Ş. }\end{array}$ & $\begin{array}{l}\text { Uzun vadeli sürdürülebilir büyüme elde etmek, tüm } \\
\text { menfaat sahipleri için değer yaratmak, müşterilerin } \\
\text { ve çalışanların ilk tercihi olmak. } \\
\text { (www.yapikredi.com.tr) }\end{array}$ & $\begin{array}{l}\text { Finans sektörünün tartışmasız lideri } \\
\text { olmak. (www.yapikredi.com.tr) }\end{array}$ \\
\hline
\end{tabular}

Tablo 2'de görüldügüü üzere özel sermayeli mevduat bankalar olan Adabank A.Ş., Akbank A.Ş., Anadolubank A.S.., Fibabank A.Ş., Şekerbank A.Ş., SSekerbank A.Ş., Turkish Bank A.Ş., Türk Ekonomi Bankası A.S.,., Türkiye İş Bankası A.Ş., Yapı ve Kredi Bankası A.Ş.'nin misyon ve vizyon ifadeleri bulunmaktadır. Adabank A.Ş.'nin web sitesi incelendiğinde web sitesinde paylaşılmış olan bir misyon ve vizyon bildirisine rastlanmamıștır. Akbank A.Ş.'nin misyon ifadesinde girișimcilik özelliklerinden herhangi birine rastlanmazken vizyon ifadesinde proaktiflik özelliğine vurgu yapılmıştır. Fibabank A.Ş.'nin misyon ve vizyon ifadelerinde girişimcilik özelliklerinden herhangi birine rastalanmıştır. Şekerbank A.Ş.'nin misyon ifadesinde güçlülük boyutuna vurgu yapılırken; vizyon ifadesinde “... lider banka olmak" diyerek liderlik boyutuna vurgu yapmıştır. Turkish Bank A.Ş.'nin misyon ifadesinde girişimcilik özelliklerinden yenilikçilik boyutuna vurgu yapılırken; visyon ifadesinde ise rekabetçilik boyutuna vurgu yapılmıștır. Türk Ekonomi Bankası A.Ș.'nin misyon ifadesinde Risk Alma boyutuna vurgu yapılırken; vizyon ifadesinde liderlik ve yenilikçilik boyutu vurgulanmıştır. Türkiye İş Bankası A.Ş.'nin web sitesinde misyon ifadesi bulunmamaktadır; stratejik anaçlar bilgisi vermiştir; vizyon ifadesinde ise girişimcilik özellikleri boyutlarından herhangi birine rastlanmamıștır. Yapı ve Kredi Bankası A.Ş.'nin misyon ifadesinde “...müşterilerin ve çalışanların ilk tercihi olmak” diyerek liderlik boyutuna vurgu yapmış; aynı şekilde vizyon ifadesinde de liderlik boyutuna vurgu yapmıştır. Tüm bu bulgulardan hareketle özel sermayeli mevduat bankalarının gerek misyon ifadesinde gerek vizyon ifadesinde liderlik ve yenilikçilik boyutu ön plana çıkmıştır.

Tablo 3. Tasarruf Mevduatı Sigorta Fonuna Devredilen Bankaların Misyon ve Vizyon İfadeleri

\begin{tabular}{|c|c|c|}
\hline BANKA & MİSYON & VİZYON \\
\hline $\begin{array}{l}\text { BİRLEŞİK } \text { FON } \\
\text { BANKASI A.Ş. }\end{array}$ & $\begin{array}{l}\text { Bankacılı işlemleri alanında daha önce } \\
\text { devralınan nakdi ve gayrinakdi kredilerle ilgili; } \\
\text { izleme ve yeniden yapılandırma çalışmaları ile } \\
\text { banka bünyesinde birleştirilen bankaların varlık } \\
\text { ve yükümlülüklerinin takip ve tasfiye işlemlerini } \\
\text { kurumsal yönetim ilkeleri çerçevesinde } \\
\text { sürdürmektir. } \\
\text { (fonbank.com.tr) }\end{array}$ & $\begin{array}{l}\text { Sosyal sorumluluk ve yüksek görev bilinci } \\
\text { içerisinde, şeffaf ve hesap verebilirlik } \\
\text { ilkeleri esas alınarak faaliyetlerimizi etkin } \\
\text { şekilde yerine getirerek, devredilen } \\
\text { bankaları en uygun şekilde çözüme } \\
\text { kavuşturmak, hak sahipleri için değer } \\
\text { yaratmak ve çalışanlarımızın gelişimine } \\
\text { katkıda bulunmaktır. } \\
\text { (fonbank.com.tr) }\end{array}$ \\
\hline
\end{tabular}

Tablo 3'te tasarruf mevduatı sigorta fonuna devredilen bankalardan olan Birleşik Fon Bankası A.Ş.'nin misyon ve vizyon ifadesi yer almaktadır. Misyon ve vizyon ifadesinde girişimcilik özelliklerinden herhangi birine rastlanmamıștır. 
Tablo 4. Türkiye'de Kurulmuş Yabancı Sermayeli Bankaların Misyon ve Vizyon İfadeleri

\begin{tabular}{|c|c|c|}
\hline BANKA & MİSYON & VİZYON \\
\hline $\begin{array}{l}\text { ALTERNATİF } \\
\text { BANK A.Ş. }\end{array}$ & $\begin{array}{l}\text { Yetkin insan kaynağımız ve sunduğumuz } \\
\text { terzi usulü çözümlerle müşterilerimize } \\
\text { büyüme yolculuklarında destek vermek. } \\
\text { "Basiretli Bankacılık" anlayışımız, } \\
\text { "Kusursuz Hizmet" yaklaşımımız ve "Danışman } \\
\text { Banka" yetkinliğimiz ile bankacılık sektöründe } \\
\text { fark yaratmak. (alternatifbank.com.tr) }\end{array}$ & $\begin{array}{l}\text { Hissedarımız The Commercial Bank'tan } \\
\text { aldığımız güçle, Türkiye'de reel sektöre ve } \\
\text { üretime yüksek katma değerli bilgi, yetkinlik } \\
\text { ve sermaye aktarımı sağlarken, çözüm odaklı } \\
\text { yaklaşımımızla müşterilerimizin danıştığı ve } \\
\text { tercih ettiği ilk banka olmaktır. } \\
\text { (alternatifbank.com.tr) }\end{array}$ \\
\hline $\begin{array}{l}\text { ARAP TÜRK } \\
\text { BANKASI A.Ş. }\end{array}$ & $\begin{array}{l}\text { - Sunmuş olduğu güvenilir ve kaliteli hizmet } \\
\text { sayesinde iç ve dış müşteri memnuniyetini en } \\
\text { üst seviyede tutan, } \\
\text { - Müşterilerine yakın, birlikte çalışılması kolay } \\
\text { olan, } \\
\text { - Etik değerleri ve sosyal sorumluluk bilincini } \\
\text { göz önüne alarak faaliyet sergileyen, } \\
\text { - Yenilik ve gelişmelere açık olan, } \\
\text { - Etkin risk yönetiminden ödün vermeden } \\
\text { sürdürülebilir büyümeyi esas alan } \\
\text { - Müşterilerine, çalışanlarına, hissedarlarına ve } \\
\text { ekonomiye kattığı değeri sürekli ve belirgin bir } \\
\text { şekilde artıran bir banka olmak. } \\
\text { (atbank.com.tr) }\end{array}$ & $\begin{array}{l}\text { Yerel pazarda sürdürülebilir ve kârlı bir } \\
\text { büyüme sağlayarak Türkiye ile Afrika ve Orta } \\
\text { Doğu ülkeleri arasındaki bankacılık } \\
\text { işlemlerinde en cok tercih edilen ve en iyi } \\
\text { hizmeti sunan banka olmak. } \\
\text { (atbank.com.tr) }\end{array}$ \\
\hline $\begin{array}{l}\text { BANK OF CHINE } \\
\text { TURKEY A.Ş. }\end{array}$ & $\begin{array}{l}\text { Web sitesinde paylaşılmış bir misyon bildirisi } \\
\text { bulunmamaktadır. (www.bankofchine.com.tr) }\end{array}$ & $\begin{array}{l}\text { Web sitesinde paylaşılmış bir vizyon bildirisi } \\
\text { bulunmamaktadır. } \\
\text { (www.bankofchine.com.tr) }\end{array}$ \\
\hline BURGAN BANK A.Ş. & $\begin{array}{l}\text { Burgan Bank, güven ve dürüstlük üzerine inşa } \\
\text { edilmiş ilişkiler kapsamında, uzman finansal ve } \\
\text { yatırım çözümleri sunarak işinizin ve şahsi } \\
\text { varlığınızın büyümesine yardım eden finansal } \\
\text { iş ortağınızdır. (www.burgan.com.tr) }\end{array}$ & $\begin{array}{l}\text { Finansal hizmetler sektöründe en iyi } \\
\text { uygulamaları, yenilikçiliği ve paydaşlarına } \\
\text { değer katan hizmetleri sürekli hayata } \\
\text { geçirerek, kendi sinıfında Türkiye'nin en iyi } \\
\text { hizmet sağlayıcısı } \\
\text { (www.burgan.com.tr) }\end{array}$ \\
\hline CITIBANK A.Ş. & $\begin{array}{l}\text { Web sitesinde paylaşılmış bir misyon bildirisi } \\
\text { bulunmamaktadır. } \\
\text { (www.citibank.com.tr) }\end{array}$ & $\begin{array}{l}\text { Web sitesinde paylaşılmış bir vizyon bildirisi } \\
\text { bulunmamaktadır. } \\
\text { (www.citibank.com.tr) }\end{array}$ \\
\hline DENİZBANK A.Ş. & $\begin{array}{l}\text { DenizBank'ın misyonu, finansal hizmetlerde bir } \\
\text { süpermarket yaklaşımı benimseyerek } \\
\text { sektördeki pozisyonu, imajı ve kurumsal } \\
\text { nitelikleri ile çalışanının, müşterisinin ve } \\
\text { hissedarının memnuniyetini maksimize eden } \\
\text { bir banka olmaktır. (www.denizbank.com) }\end{array}$ & $\begin{array}{l}\text { DenizBank'ın vizyonu, sürdürülebilir ve karlı } \\
\text { büyümeyi sağlayarak Türkiye'deki ilk bes } \\
\text { banka arasında yer alıp uluslararası finansal } \\
\text { ortamın bölgemizdeki en güçlü ortağı } \\
\text { olmaktır. Söz konusu bölge Orta Doğu, } \\
\text { Kafkaslar, Balkanlar ve Bağımsız Devletler } \\
\text { Topluluğu Ülkeleri'dir. } \\
\text { (www.denizbank.com) }\end{array}$ \\
\hline $\begin{array}{l}\text { DEUTSCHEBANK } \\
\text { A.Ş. }\end{array}$ & $\begin{array}{l}\text { Misyonumuz, yüksek talepleri olan müşterilere } \\
\text { finansal çözümler sağlayan küresel bir kuruluş } \\
\text { olmak için rekabet ederken ortaklarımız ve } \\
\text { çalıştığımız kişiler için yüksek değerler } \\
\text { yaratmaktır. (www.db.com) }\end{array}$ & $\begin{array}{l}\text { Başarı tutkusu bizim iş yapma biçimimizdir. } \\
\text { Mükemmelliği arar, benzersiz yaklaşımlarla } \\
\text { yenilikçi çözümler üretir ve uzun soluklu } \\
\text { ilişkiler kurarı. (www.db.com) }\end{array}$ \\
\hline HSBC BANK A.Ş. & $\begin{array}{l}\text { Tarihimiz boyunca büyüme neredeyse orada } \\
\text { bulunduk ve müşterilerimizi firsatlarla } \\
\text { buluşturduk. Şirketlerin büyümesine, } \\
\text { ekonomilerin gelişmesine katkıda bulunmak ve } \\
\text { bu sayede insanların hayallerine ulaşmalarına } \\
\text { ve hedeflerini gerçekleștirmelerine yardımcı } \\
\text { olmak bizim görev ve misyonumuzdur. } \\
\text { (hsbc.com.tr) }\end{array}$ & $\begin{array}{l}\text { Türkiye'nin önde gelen uluslararası bankası } \\
\text { olmak. (hsbc.com.tr) }\end{array}$ \\
\hline
\end{tabular}




\begin{tabular}{|c|c|c|}
\hline $\begin{array}{l}\text { ICBC TURKEY } \\
\text { BANK A.Ş. }\end{array}$ & $\begin{array}{l}\text { Müşterilerimizin mevcut ve gelecekteki } \\
\text { ihtiyaçları için özel çözümler üretmek, bilgi ve } \\
\text { yaratıcılığa dayalı kaliteli hizmet } \\
\text { anlayışımızla kalıcı ilişkiler kurmak, sosyal ve } \\
\text { ekonomik değer yaratarak ülke ekonomisine } \\
\text { katkıda bulunmak, müșterilerimiz, } \\
\text { çalışanlarımız, pay sahiplerimiz için sürekli } \\
\text { değer yaratmaktır. (ıcbc.com.tr) }\end{array}$ & $\begin{array}{l}\text { Uluslararası bankacılık anlayışı çerçevesi } \\
\text { içerisinde, yenilikçi, gelişmeye açı, süratli, } \\
\text { titiz, kaliteli hizmet sunan ve muhafazakâr } \\
\text { risk yaklaşımı ile müşterilerin öncelikle } \\
\text { tercih ettiği banka olmaktır. (ıcbc.com.tr) }\end{array}$ \\
\hline ING BANK A.Ş. & $\begin{array}{l}\text { Web sitesinde paylașılmış bir misyon bildirisi } \\
\text { bulunmamaktadır. (www.ing.com.tr) }\end{array}$ & $\begin{array}{l}\text { Web sitesinde paylaşılmış bir vizyon bildirisi } \\
\text { bulunmamaktadır. (www.ing.com.tr) }\end{array}$ \\
\hline $\begin{array}{l}\text { MUFGBNAK } \\
\text { TURKEY A.Ş. }\end{array}$ & $\begin{array}{l}\text { MUFG Bank'ın dünya çapındaki ağını ve } \\
\text { finansal gücünü kullanarak Türkiye'nin } \\
\text { büyümesine katkı sağlamak. } \\
\text { (www.tu.bk.mufg.jp) }\end{array}$ & $\begin{array}{l}\text { •Müşterilerimiz, paydaşlarımız ve toplum } \\
\text { için en güvenilir finansal kuruluş olmak } \\
\text { •Türkiye ile Japonya ve Türkiye ile dünya } \\
\text { arasında Finansal bir köprü olmak. } \\
\text { •Müşterilerimize yerel ve uluslararası } \\
\text { destek vermek. } \\
\text { (www.tu.bk.mufg.jp) }\end{array}$ \\
\hline ODEA BANK A.Ş. & $\begin{array}{l}\text { Misyonumuz, bankacılıkta en iyiye yatırım } \\
\text { yaparak paydaşlarımızın mutluluklarını } \\
\text { hedeflemek, hayatlarını önemseyen bir anlayışı } \\
\text { onlara sunmaktır.(odeabank.com.tr) }\end{array}$ & 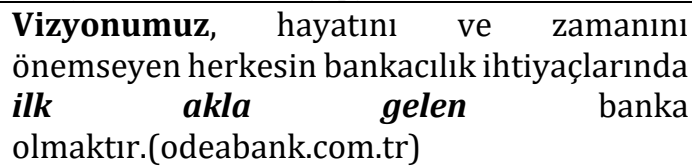 \\
\hline $\begin{array}{l}\text { QNB FINANSBANK } \\
\text { A.Ş. }\end{array}$ & $\begin{array}{l}\text { QNB Finansbank'a dokunan herkesle, } \\
\text { ihtiyaçları anlamaya, doğru çözümler üretmeye } \\
\text { ve memnuniyete dayalı, mutlaka başarmayı } \\
\text { hedefleyen yaşam boyu sürecek bir ortaklık } \\
\text { kurmak. } \\
\text { (qnbfinansbank.com) }\end{array}$ & $\begin{array}{l}\text { Türkiye'yi başarıya taşıyacak her bireysel ve } \\
\text { ticari finansal planın mimarı olmak. } \\
\text { (qnbfinansbank.com) }\end{array}$ \\
\hline RABOBANK A.Ş. & $\begin{array}{l}\text { Rabobank AŞ’nin misyonu, paydaşlarımızın } \\
\text { ekonomik ihtiyaçlarına hizmet etmektir. } \\
\text { (rabobank.com.tr) }\end{array}$ & $\begin{array}{l}\text { Rabobank AŞ, hem özel ve hem de kamu } \\
\text { sektörüne hizmet ederek reel ekonomiye } \\
\text { katkıda bulunmayı hedeflemektedir. } \\
\text { Organizasyonumuzun hangi kademesinde } \\
\text { olursa olsun; tüm çalışanlarımız bu çabamızın } \\
\text { sonuçlanmasında kilit rol sahibidir. } \\
\text { Müşterilerinin her zaman yanında yer alan } \\
\text { Bankamız, sürdürülebilir kalkınmaya } \\
\text { odaklanmıştır. } \\
\text { (rabobank.com.tr) }\end{array}$ \\
\hline $\begin{array}{l}\text { TURKLAND BANK } \\
\text { A.Ș. }\end{array}$ & 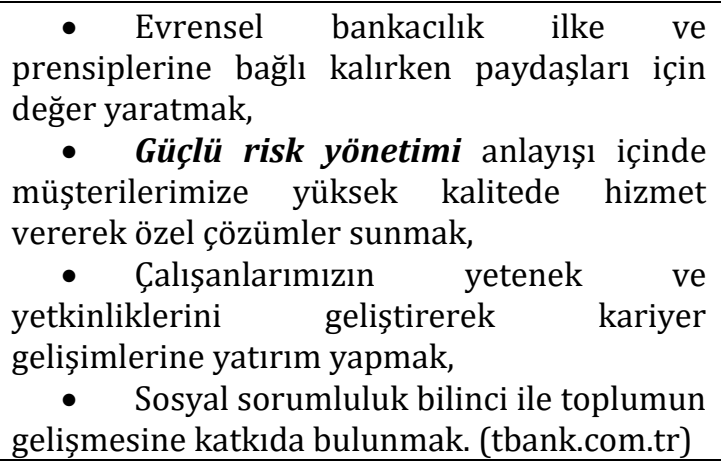 & $\begin{array}{l}\text { Ekonominin büyüyen sektörlerine finansal } \\
\text { hizmet sunumunda öncü bir banka } \\
\text { olmak.(tbank.com.tr) }\end{array}$ \\
\hline $\begin{array}{l}\text { TÜRKIYE GARANTİ } \\
\text { BANKASI A.Ş. }\end{array}$ & $\begin{array}{l}\text { Web sitesinde paylaşılmış bir misyon bildirisi } \\
\text { bulunmamaktadır. } \\
\text { (garantibbva.com.tr) }\end{array}$ & $\begin{array}{l}\text { Web sitesinde paylaşılmış bir vizyon bildirisi } \\
\text { bulunmamaktadır. } \\
\text { (garantibbva.com.tr) }\end{array}$ \\
\hline
\end{tabular}

Tablo 4'te Türkiye'de kurulmuş olan yabancı sermayeli bankalar olan; Alternatif Bank A.Ş., Arap Türk Bankası A.Ş., Bank Of Chine Turkey A.Ş., Burgan Bank A.Ş., Citibank A.Ş., Denizbank A.Ş., Deutschbank A.Ş., Hsbc Bank A.Ș., Icbc Turkey Bank A.Ș., Ing Bank A.Ş., Mufgbank A.Ş., Odea Bank A.Ş., Qnb Finansbank A.Ş., Rabobank A.Ş., Turkland Bank A.Ş., Türkiye Garanti Bankası A.Ş.'nin misyon ve 
vizyon ifadeleri bulunmaktadır. Alterantif Bank A.Ş.'nin misyon ifadesinde “... fark yaratmak" ifadesi ile rekabetçilik boyutuna vurgu yapılırken; vizyon ifadesinde "...ilk banka" ifadesi ile liderlik boyutuna vurgu yapılmıștır. Arap Türk Bankası A.Ş.'nin misyon ifadesinde yenilikçilik boyutuna vurgu yapılırken; vizyon ifadesinde "... en çok tercih edilen, en iyi hizmeti sunan banka olmak" ifadeleri ile liderlik ve rekabetçilik boyutlarına vurgu yapılmıştır. Bank of Chine Turkey A.Ş.'nin web sitesinde paylaşılmış olan misyon ve vizyon bildirisi bulunmamaktadır. Burgan Bank A.Ş.'nin misyon ifadesinde girişimcilik özellikleri boyutlarından herhangi birine rastlanmazken; vizyon ifadesinde "...en iyi, ... yenilikçilik" gibi ifadeler kullanarak rekabetçilik ve yenilikçilik boyutlarına vurgu yapılmıştır. Citibank A.Ş.'nin web sitesinde paylaşılmış olan misyon ve vizyon bildirisi bulunmamaktadır. Denizbank A.Ş.'nin misyon ifadesinde girişimcilik özellikleri boyutlarından herhangi birine rastlanmazken; vizyon ifadesinde “... Türkiye'deki ilk beş banka..." ifadesi ile liderlik boyutuna; "... en güçlü" ifadesi

ile ise güçlülük boyutuna vurgu yapılmıştır. Deutschebank A.Ş.'nin misyon ifadesinde rebaketçilik boyutuna; vizyon ifadesinde ise başarı ve yenilikçilik boyutuna vurgu yapılmıştır. Hsbc Bank A.Ş.'nin misyon ifadesinde girişimcilik özelliklerinden herhangi birine rastlanmazken; vizyon ifadesinde “...önde gelen..." ifadesi ile liderlik boyutuna vurgu yapılmıștır. Icbc Bank A.Ș.'nin misyon ifadesinde yaratıcık boyutuna vurgu yapılırken; vizyon boyutunda yenilikçilik, risk alma, liderlik boyutlarına vurgu yapılmıştır. Ing Bank A.Ş.'nin web sitesinde paylaşılmış olan misyon ve vizyon bildirisi bulunmamaktadır. Mufgbank Turkey A.Ş.'nin misyon ve vizyon ifadelerinde girişimcilik özellikleri boyutlarından herhangi birine rastlanmamıştır. Odea Bank A.Ș.'nin misyon ifadesinde girişimcilik özellikleri boyutlarından herhangi birine rastlanmazken; vizyon ifadesinde liderlik boyutuna vurgu yapılmıştır. Qnb Finanbank A.Ş.'nin misyon ifadesinde girişimcilik özellikleri boyutlarından herhangi birine rastlanmazken; vizyon ifadesinde başarı boyutu vurgulanmıștır. Rabobank A.Ş.'nin misyon ve vizyon ifadelerinde girişimcilik özellikleri boyutlarından herhangi birine rastlanmamıștır. Turkland Bank A.Ş.'nin misyon ifadesinde risk alma boyutu vurgulanırken; vizyon ifadesinde liderlik boyutu vurgulanmıştır. Tükiye Garanti Bankası A.Ş.'nin web sitesinde paylaşılmış olan misyon ve vizyon bildirisi bulunmamaktadır.

Tablo 5. Türkiye'de Şube Açan Yabancı Sermayeli Bankaların Misyon ve Vizyon İfadeleri

\begin{tabular}{|c|c|c|}
\hline BANKA & MİSYON & VİZYON \\
\hline BANK MELLAT & $\begin{array}{l}\text { Dış ticaret alanında, İran ve Türkiye'deki } \\
\text { kuruluşlara uzman, geniş ölçekli, yenilikçi, } \\
\text { etkin ve yüksek kalitede hizmetler sunmak ve } \\
\text { bu alanda kurumumuzdan beklenilenin } \\
\text { üzerine çıkmak. (mellatbank.com.tr) }\end{array}$ & $\begin{array}{l}\text { Türkiye ile İran İslam Cumhuriyeti } \\
\text { arasındaki dış ticareti ve } \\
\text { finansman işlemlerini } \\
\text { gerçekleştirmede lider bir bank } \\
\text { olmak ve bu konumu devamlı } \\
\text { artan bir paylaşımla } \\
\text { korumaktadır. } \\
\text { (mellatbank.com.tr) }\end{array}$ \\
\hline HABİB BANK LİMİTED & $\begin{array}{l}\text { Misyonumuz müşterilerimizin güçlenmesi, } \\
\text { çalışanlarımızın gelişimi ve hissedarlarımıza } \\
\text { katma değer sağlamaktır. (hbl.com.tr) }\end{array}$ & $\begin{array}{l}\text { Vizyonumuz insanların güven ve } \\
\text { başarıyla gelişmesidir. } \\
\text { (hbl.com.tr) }\end{array}$ \\
\hline INTESA SANPAOLO S.P.A. & $\begin{array}{l}\text { Misyonumuz, müşterilerimiz için } \\
\text { tekliflerimizi, fiyatlarımızı ve hizmet kalitemizi } \\
\text { genişleterek ve geliştirerek, kaynaklarımızın } \\
\text { verimli ve etik kullanımını garanti altına almak, } \\
\text { güvenilir ve güvenilir bir işletme olarak } \\
\text { mükemmellik ve en yüksek hizmet seviyelerini } \\
\text { sağlamaktır. (imi.intesasanpaolo.com) }\end{array}$ & \begin{tabular}{lr} 
Vizyonumuz, & \multicolumn{2}{c}{ müşterilerimizin } \\
ihtiyaçlarını karşılamak ve tüm \\
paydaşlarımızın ve Intesa Sanpaolo \\
Grubunun yararına ticari \\
faaliyetlerimizin \\
segmentlerinde sürekli yüksek \\
kaliteyi sağlamak için tüm \\
profesyonellik ve deneyimimizi \\
adamaktır. \\
(imi.intesasanpaolo.com)
\end{tabular} \\
\hline
\end{tabular}




\begin{tabular}{|l|l|l|}
\hline JPMORGAN CHASE BAK N.A. & $\begin{array}{l}\text { Web sitesinde paylaşılmış bir misyon bildirisi } \\
\text { bulunmamaktadır. } \\
\text { (jpmorgan.com) }\end{array}$ & $\begin{array}{l}\text { Web sitesinde paylaşılmış bir vizyon } \\
\text { bildirisi bulunmamaktadır. } \\
\text { (jpmorgan.com) }\end{array}$ \\
\hline SOCIÉTÉ GÉNÉRALE (SA) & $\begin{array}{l}\text { Web sitesinde paylaşılmış bir misyon bildirisi } \\
\text { bulunmamaktadır. } \\
\text { (societegenerale.com.tr) }\end{array}$ & $\begin{array}{l}\text { Web sitesinde paylaşılmış bir vizyon } \\
\text { bildirisi bulunmamaktadır. } \\
\text { (societegenerale.com.tr) }\end{array}$ \\
\hline
\end{tabular}

Tablo 5'te Türkiye'de şube açan yabancı sermayeli bankalardan olan; Bank Mellat, Habib Bank Limited, Intesa Sapaolo S.P.A., Jpmorgan Chase Bank N.A., Société Générale (Sa) misyon ve vizyon ifadeleri bulunmaktadır. Bank Mellat'ın misyon ifadesinde yenilikçilik boyutuna vurgu yapılırken; vizyon ifadesinde liderlik boyutu ön plandadır. Habib Bank Limited'in misyon ifadesinde güçlülük boyutuna vurgu yapılmışken; vizyon ifadesinde başarı boyutu dikkat çekmektedir. JPMORGAN CHASE BANK N.A. ve SOCIÉTÉ GÉNÉRALE (SA) bankalarının ise web sitesinde paylaşılmış bir misyon bildirisi bulunmamaktadır.

\section{SONUÇ}

Girişimcilik işletmeler ve sektörler için önemli olduğu kadar toplumların kalkınması ve refahı için de önemli bir kavramdır. İnsan istek ve ihtiyaçlarını karşılamak için üreten girişimciler sadece bu istek ve ihtiyaçları karşılamakla kalmayıp hayatın devamı ve katma değer yaratmak gibi önemli sonuçlara da imza atmaktadır. Bir ülkenin ekonomik olarak kalkınması ve ülkede istihdam yaratılması için girişimcilere büyük ihtiyaç duyulmaktadır. Yerli yabancı pek çok girişimci üretim yaptığı veya hizmet sunduğu ülkede istihdam yaratarak işsizliğin azalmasına katkı sağlamakta ve ekonomik kalkınmaya destek vermektedir. Kâr elde etme, bağımsız çalışma, yüksek gelir elde etme, saygınlık kazanma gibi isteklerden hangisi ile yola çıkmış olursa olsun girişimcinin ve başarılı girişimcilerin taşıdığı birtakım ortak özellikler bulunmaktadır. Yıllardan beridir "girişimci olunur mu doğulur mu?" soruları sorulmaya devam ederken, doğuştan getirdikleri birtakım özelliklerden, girişimcilerin içinde bulunduğu toplumun kültüründen, ailesinden, aldığı eğitimlerden de sahip olduğu birtakım özellikler vardır ve bu özellikleri kendi işletmesine de yansıtmaktadır. Dolayısıyla yukarıda sayılan sebeplerden hangisinden ötürü bir işletme kurarsa kursun; işletmelerin kendilerini görmek istedikleri bir nokta yani vizyonları ve bu vizyona ulaşmak için yapması gereken misyonları bulunmaktadır. Diğer yandan girişimcilerin sahip oldukları ortak özellikler olduğu gibi anlatılan sebeple girişimcilik özellikleri de vardır ve bunlar literatürde dokuz boyutta incelenmiștir. Bu bağlamda işletmelerin misyon ve vizyon ifadelerinin hangi girişimcilik özelliklerini vurguladığı sorusu ayrı bir önem kazanmaktadır.

Bu çalışmada Türkiye'de faaliyet gösteren TBB'nin web sitesinde paylaşılmış olan -sınai ve kalkınma bankaları hariç- banka işletmelerinin web sitelerinde paylaşmış olduğu misyon ve vizyon ifadelerinin yardımıyla girişimcilik özellikleri değerlendirilmiştir. Bu doğrultuda ilgili literatür taranarak işletmelerin girişimcilik özelliklerini ifade etmede misyon ve vizyon ifadelerindeki yönlenmeyi özetlemekte anlamlı olan "; risk alma, liderlik, yenilikçilik, yaratıcılık, güçlülük, proaktiflik, araştırma ve geliştirme, başarı ve rekabetçilik" gibi boyutlar tanımlanmış ve bu bankaların misyon ve vizyon ifadeleri bu boyutlara göre incelenmiştir.

Çalışmada elde edilen bulgular sonucunda bazı bankaların web sitelerinde paylaşılmış olan bir misyon ve vizyon ifadesi bulunmamaktadır. Web sitelerinde misyon ve vizyon ifadesi paylaşan söz konusu bankaların girişimcilik özelliklerini daha çok vizyon ifadelerinde yansıttığını görülmektedir. Gerek misyon gerek vizyon ifadelerinde sıklıkla; liderlik, proaktiflik, yenilikçilik, rekabetçilik kavramları ön plana çıkmaktayken; nadiren de olsa güçlülük ve başarı boyutuna da rastlanmıştır.

Yerli Sermayeli Mevduat Bankaları açısından incelendiğinde liderlik ön planda iken; Yabancı Sermayeli Mevduat Bankaları da aynı şekilde liderlik ile ön plana çıkmakla beraber; ek olarak 
yenilikçilik, güçlülük, rekabetçilik de ön plana çıkmıştır. Tasarruf Mevduatı Sigorta Fonu'na Devredilen Banka olan Birleşik Fon Bankası'nın misyon ve vizyon ifadesinde herhangi bir boyuta rastlanmamıştır. Türkiye'de Kurulmuş Olan Yabancı Sermayeli Bankalar açısından değerlendirildiğinde sıklıkla yenilikçilik ve liderlik boyutunun ön plana çıtığı ek olarak; nadiren güçlülük, proaktiflik, yaratıcllı boyutlarının da olduğu görülmektedir. Türkiye'de Şube Açan Yabancı Sermayeli Bankalar incelendiğinde yenilikçilik, güçlülük, liderlik ve başarı boyutlarının ön plana çıktığı görülmektedir. Bu çalışma banka işletmeleri misyon ve vizyon ifadelerini oluştururken daha seçici davranmaları açısından önemli bir çalışmadır. Çalışmadan elde edilen bulgular değerlendirildiğinde Türkiye'de faaliyet gösteren bankacılık işletmelerinin liderlik, rekabetçilik ve yenilikçiliğe önem verdikleri görülmektedir. Hem misyon hem de vizyon ifadeleri açısından bakıldığında Risk Alma ve Araştırma-Geliştirme boyutlarına neredeyse hiç rastlanmadı̆̆ı, tercih edilmediği görülmektedir. Aynı şekilde yaratıcllı, proaktiflik ve başarı boyutlarının da az tercih edilmesi dikkat çekmektedir. Elbetteki misyon ve vizyon ifadelerinde belirtmedikleri için risk almadıkları, Araştırma- Geliştirmeye önem vermedikleri, yaratıcı, öncü olmadıkları söylenemez; ancak yine de düşündürücü bir durumdur. Bu alanda çalışma yapacak araştırmacılar banka işletmelerinin bu boyutları tercih edip etmediğini, tercih etmemişlerse neden tercih etmediklerini, tercih etmişlerse misyon ve vizyon ifadelerinde neden yer almadığını araştırabilir. 
Aidis, Ruta, (2003). Entrepreneurship and Economic Transition". Amsterdam: Tinbergen Institute Disccussion Paper.

Akgemci, Tahir (2007). Stratejik Yönetim. Ankara: Gazi Kitabevi.

Alam, Syed Syah (2011). Entrepreneur's Traits and Firm Innovation Capability: An Empirical Study in Malaysia. Asian Journal of Technology Innovation, Vol. 19, No.1, s. 53-66.

alternatifbank.com.tr, Erişim Tarihi: 30.08.2020

atbank.com.tr, Erişim Tarihi: 30.08.2020

Awamleh, R., Gardner, W. L. (1999). Perceptions of Leader Charisma and Effectiveness: The Effect of Vision Content, Delivery and Organizationals Performance. Leadership Quarterly. 10 (3).

Aytar, Oğuzhan, Soylu, Şerife (2017). Türk Bankacılık Sektörünün Misyon ve Vizyon İfadelerine Yönelik Bir İçerik Analizi. Kastamonu University Journal of Faculty of Economics and Administrative Sciences. Volume 17, Issue 3.

Balkan, Bülent, Kahyaoğlu, Sezer, Bozkuş (2018). Kurumsal Yönetġm Kapsamında Vizyon, Mġsyon ve Değerler: Türk Bankacılık Sektörü Üzerg̉ne Bir Değerlendirme. Muhasebe ve Vergi Uygulamaları Dergisi. Nisan 2018. Özel Sayı: 485-507.

Bart, Chris (2007). "A Comparative Analysis of Mission Statement Content in Secular and Faithbased Hospitals". Journal of Intellectual Capital, 8(4), 682- 694.

Bart, Chris and Bontıs, Nick (2003). "Distinguishing Between the Board and Management in Company Mission Implications for Corporate Governance”, Journal of Intellectual Capital 4(3), 361-381.

Beugelsdijk, Sjoerd - Noorderhaven, Niels (2004). Entrepreneurial Attitude and Economic Growth: A Cross-Section of 54 Regions. Ann Reg Sci. Vol. 38, No. 1, s.99-218.

Bird, Barbara (1989). Entrepreneurial behavior. Glenview, IL: Scott Foresman

Bozkurt, Çetinkaya Özlem, Kalkan, Adnan, Koyuncu, Osman, Alparslan, Ali Murat (2012). Türkiye'de Girişimciliğin Gelişimi: Girişimciler Üzerinde Nitel Bir Araştırma. Journal of Süleyman Demirel University Institute of Social Sciences. Year: 2012/1, Number:15

Casson, Mark (2005). Entrepreneurship and the theory of the firm. Journal of Economic Behavior \& Organization, 58(2), 327-348.

Casson, Mark (2010). Entrepreneurship: Theory, Institutions and History. Eli F. Heckscher Lecture. Scandinavian Econ. Hist. Rev. Vol.58, No.2, s. 139-170.

Clayton,Susan (2002). Takımınızın Yeteneklerini Geliştirmede Strateji Geliştirme (Çeviren: M. Zaman). İstanbul: Hayat Yayıncılık.

Colbert, Francois (2003). Entrepreneurship And Leadership İn Marketing The Arts. International Journal of Arts Management, 30-39.

Collins, Christopher, Hanges, Paul J., \& Locke, Edwi A. (2004). The relationship of achievement motivation to entrepreneurial behavior: A meta-analysis. Human performance. 17(1), 95-117.

Coskun, Recai, Geyik, Mahmut. (2004). "Küresel Firmaların Misyon İfadeleri Yerelliğe Ne Kadar Vurgu Yapıyor?”,.12. Ulusal Yönetim ve Organizasyon Kongresi Kitabı. Uludağ Üniversitesi İ.İ.B.F. İşletme Bölümü, 27- 29 Mayıs, Bursa, 287-294.

Covin, Jeffrey G. \& Slevin, Dennis P. (1986). The development and testing of an organizationallevelentrepreneurship scale. in Ronstadt, R., Hornaday, J.A. and Vesper, K.H. (Eds). Frontiersof Entrepreneurship Research. Babson College, Wellesley, MA, pp. 628-39.

Cuckovic, Nevenka., \& Bartlett, Will (2007). Entrepreneurship and Competitiveness: The Europeanisation of Small and Medium-sized Enterprise Policy in Croatia. Southeast European and Black Sea Studies. 7(1), 37-56. 
Czinkota, Michael R., Ronkainen, Ilkka A. ve Moffett, Michael H. (2009). International Business. Wiley: European Business Edition.

Darbi, William P. K. (2012), "Of Mission and Vision Statements and Their Potential Impact on Employee Behaviour and Attitudes: The Case of A Public But Profit-Oriented Tertiary Institution". International Journal of Business and Social Science. Vol. 3, No: 14, s. 95-109.

Değerlendirilmesi: 5 Yıldızlı Konaklama İşletmeleri Örneği. Kastamonu Üniversitesi İktisadi ve İdari Bilimler Dergisi. Sayı 9.

Deliz, José R. (1997). Lessons Learned From Baldrige Winners. 21st International Conference on Computers and Industrial Engineering. 33. 1-2.

Dinçer, Ömer (1996). Stratejik Yönetim ve Isşletme Politikası. İstanbul:Beta Yayınları.

Dinçer, Ömer (2003). Stratejik Yönetim ve İşletme Politikası. (6. Baskı). İstanbul:Beta Yayınları.

Drucker, Peter (2012). Yönetim. (Çev. İlker Gülfidan). İstanbul: Optimist Kitap.

Eken İnan, Ümmü Saliha (2019). "Selçuk Üniversitesine Bağlı Meslek Yüksekokullarının Kalite Yolculuğunda Oluşturulan Misyon ve Vizyon İfadelerinin Değerlendirilmesi”. Journal of Social and Technical Researches. Vol: 18 Page: 41-49.

Eren, Erol (2005). Stratejik Yönetim ve İşletme Politikası. (7. Baskı). İstanbul: Beta Yayınları.

Erken, Hugo (2008). Productivity, R\&D and entrepreneurship (No. EPS-2008-147-ORG). Erasmus Research Institute of Management (ERIM).

Erol, Yüce, Kanbur, Engin (2014). Misyon ve Vizyon İfadelerine Göre Türkiye'nin İlk 100 Büyük Şirketinin Girișimcilik Özellikleri. Business and Economics Research Journal Volume 5 Number

3 pp. $149-165$ ISSN: $1309-2448$

Ertuna, Özer (2008). Stratejik Yönetim. İstanbul: Okan Üniversitesi Yayınları:4.

Eyal, Ori - Kark, Ronit (2004). How do Transformational Leaders Transform Organizations? A Study of the Relationship Between Leadership and Entrepreneurship?. Leadership and Policy in Schools, Vol. 3, No: 3, s. 211-235.

fonbank.com.tr, Erișim Tarihi: 30.08.2020

Foxall, G. R. - Minkes, A. L. (1996). Beyond Marketing: The Diffusion of Entrepreneurship in the Modern Corporation. Journal of Strategic Marketing. Vol. 4, No: 2, s. 71-93.

garantibbva.com.tr, Erişim Tarihi: 30.08.2020

Gill, Roger (2003). Change Management or Change Leadership? Journal of Change Management. 3 (4).

GÖKÇE, Orhan (2006). İçerik Analizi Kurumsal ve Pratik Bilgiler. Siyasal Kitabevi, Ankara.

Graneheim, Ulla Hällgren, Lundman, Berit (2004). Qualitative content analysis in nursing research: concepts, procedures and measures to achieve trustworthiness. Nurse education today. 24(2), 105-112.

Greblikaitë, Jolita - Daugëlienë, Rasa (2009). Cluster Analysis of Expression of Entrepreneurship Characteristics in the EU Innovative Projects for SME's and KTU Regional Science Park. European Integration Studies. No: 3, s. 184-189.

Güney, Salih (2004). Açıklamalı Yönetim-Organizasyon ve Örgütsel Davranış Terimler Sözlüğü. Ankara: Siyasal Kitabevi.

Gürüz, Demet, Gürel, Emet, (2009). Bireyden Örgüte, Fikirden Eyleme Yönetim ve Organizasyon. Ankara: Nobel Yayın Dağıtım.

Hayward, Mathew L., Shepherd, Dean A., \& Griffin, D. (2006). A hubris theory of entrepreneurship. Management Science, 52(2), 160-172.

hbl.com.tr, Erişim Tarihi: 30.08.2020

Henry, Anthony (2008). 'Understanding Strategic Management'. Oxford University Press, Ch:1 pp.11-12.

Hisrich, R. D., and Peters, M. P. (2002). Entrepreneurship, Mcgraw-Hill Irwin. Fifth Edition, USA. 
Hodgkinson, C. (2008). Yönetim Felsefesi, Örgütsel Yaşamda Değerler ve Motivasyon. (Çev: İ. Anıl, B. Doğan). İstanbul: Beta Yayım.

Holt, Daniel T. - Rutherford, Matthew W. - Clohessy, Gretchen R. (2007). Corporate Entrepreneurship: An Empirical Look at Individual Characteristics, Context, and Process. Journal of Leadership and Organizational Studies. Vol. 13, No: 4, s. 40-54.

hsbc.com.tr, Erişim Tarihi: 30.08.2020

https://sozluk.gov.tr/, Erişim Tarihi: 10.08.2020.

https://www.tbb.org.tr/modules/banka-bilgileri/banka_sube_bilgileri.asp, Erişim Tarihi: 30.08.2020

Hultman, Ken (2005). Evaluating Organizational Values. Organizational Development Journal. 23 (4). 32-44.

icbc.com.tr, Erişim Tarihi: 30.08.2020

Ireland, Duane R. - Webb, Justin W. (2007). Strategic Entrepreneurship: Creating Competitive Advantage through Streams of Innovation. Business Horizons. Vol. 50, s. 49-59.

imi.intesanpaolo.com, Erişim Tarihi: 30.08.2020

İraz, Rıfat (2005). Yaratıcılık ve Yenilik Bağlamında Girişimcilik Ve Kobiler. Konya: Çizgi

Jacobsen, Joseph. (2011). Sustainable Business\&Industry. Milwaukee: Quality Press.

Johnson, Bradley R. (1990). Toward a multidimensional model of entrepreneurship: The case of achievement motivation and the entrepreneur. Entrepreneurship Theory and practice, 14(3), 39-54.

jpmorgan.com, Erișim Tarihi: 30.08.2020

Karabulut, Tuğba A. (2007). "A Study on Two Fundamental Tools of Strategic Management: Mission and Vision Statements". The Proceedings Book of 3rd International Strategic Management Conference, Tübitak.

Kılıç, Mustafa (2010). Stratejik Yönetim Sürecinde Değerler, Vizyon ve Misyon Kavramları Arasındaki İlişki. Sosyo Ekonomi. Temmuz-Aralık 2010-2. pp. 81-97.

Koçel, Tamer (2003). İşletme Yöneticiliği. (9. Basım). İstanbul:Beta Yayınları.

Köseoğlu, Mehmet Ali (2008). İşletmeler Var Olma Sebeplerini Nasıl İfade Ederler? KOBİlerin Misyon İfadeleri Üzerine Bir Araştırma. Celal Bayar Üniversitesi İİBF, Yönetim ve Ekonomi. Cilt: 15 Sayı: $2 \mathrm{~s}$

Kukkurainen, Marja Leena, Suominen, Tarja, Rankinen, Sirkku, Harkönen, Eeva, Kuokkanen, Liisa (2012). Organizational Vision: Experience At The Unit Level. Journal of Nursing Management. 20, 868-876.

Lee, Sam Youl, Florida, Richard, \& Acs, Zoltan (2004). Creativity and entrepreneurship: a regional analysis of new firm formation. Regional studies, 38 (8), 879-891.

Li, Yuan - Liu, Yi - Zhao, Yongbin (2006). The Role of Market and Entrepreneurship Orientation and Internal Control in the New Product Development Activities of Chinese Firms. Industrial Marketing Management. Vol. 35, s. 336-347.

Macko, Anna, \& Tyszka, Tadeusz (2009). Entrepreneurship and Risk Taking. Applied Psychology, 58 (3), 469-487.

Markman, Gideon D. - Baron, Robert A. (2003). Person-Entrepreneurship Fit: Why Some People Are More Successful as Entrepreneurs than Others. Human Resource Management Review. Vol. 13, s. 281-301.

Mason, Colin - Harvey, Charles (2013). Entrepreneurship: Contexts, Opportunities and Processes. Business History. Vol. 55, No: 1, s. 2013, 1-8.

mellatbank.com.tr, Erişim Tarihi: 30.08.2020 
Moin, Muhammad F. - Ali, Ahsan - Khan, Ali N. (2012). "An Analysis of Mission Statement of Pakistani Commercial (Scheduled) Banks Using A Nine Points Scale Approach of Fred R. David". Interdisciplinary Journal of Contemporary Research in Business. Vol. 4, No: 2, s. 102-120.

Müftüoğlu, Tamer, Haliloğlu, Necla (2013). Nasıl Girişimci Olunur? Genişletilmiş 3. Baskı. Ankara: Turhan Kitabevi.

Obschonka, Martin, Silbereisen, Raiver, K., \& Schmitt-Rodermund, Eva (2010). Entrepreneurial intention as developmental outcome. Journal of Vocational Behavior. 77(1), 63-72.

odeabank.com.tr, Erişim Tarihi: 30.08.2020

Oruç, Civelek Makbule, Zengin, Burhanettin (2015). Misyon Vizyon Bildirilerinin Müşteri Odaklılık Yönünden

Öztürk, Ali O. (2012). Kamu Örgütlerinde Girişimcilik. Işs Güç Endüstri İlişkileri ve İnsan Kaynakları Dergisi. Cilt. 14, Sayı. 4, s. 151-169.

Pearce, John A. ve David, Fred (1987). “Corporate Mission Statemens: The Bottom Line”. Academy of Management Execute. Vol:1, No:2, pp.109-116.

Peetz, Ted B. - Reams, Lamar (2011). A Content Analysis of Sport Marketing Quarterly: 1992-2011. Sport Marketing Quarterly. Vol. 20, No: 4, s. 209-218.

Popp, Andrew - Holt, Robin (2013). The Presence of Entrepreneurial Opportunity. Business History. Vol. 55, No: 1, s. 9-28.

Posner, B. Z. ve Schmidt, W. H. (1992). Values And The American Manager: An Update Updated. California Management Review, 34: 80-94.

qubfinansbank.com, Erişim Tarihi: 30.08.2020

Quicgley, Joseph V. (1998). Vizyon Oluşturulması Geliştirilmesi ve Korunması, (Çeviri: Berat Çelik). İstanbul: Epsilon Yayınları.

rabobank.com.tr, Erişim Tarihi: 30.08.2020

Rauch, Andreas - Frese, Michael (2007). Let's Put The Person Back into Entrepreneurship Research: A Meta-Analysis on The Relationship Between Business Owners' Personality Traits, Business Creation and Success. European Journal of Work and Organizational Psychology. Vol. 16, No: 4, s. 353-385.

Schmitt-Rodermund, E. (2004). Pathways to successful entrepreneurship: Parenting, personality, early entrepreneurial competence, and interests. Journal of Vocational Behavior, 65(3), 498518.

societegenerale.com, Erişim Tarihi: 30.08.2020

Spilling, Olav R. - Rosenberg, Ovar A. (2008). To Eat or To Be Eaten-on The Role of Entrepreneurship in The Norwegian Telecom Access Sector. Entrepreneurship \& Regional Development, An International Journal. Vol. 20, No: 1, s. 19-40.

Tanković, A.Č. (2013). Defining Strategy Using Vision and Mission Statements of Croatian Organizations In Times of Crisis, the 6th International Conference "The Changing Economic Landscape: Issues, Implications and Policy Options”. May 30th - June 1, 331-342.

tbank.com.tr, Erişim Tarihi: 30.08.2020

Tekin, Mahmut (2004). Girişimcilik ve Küçük Isşletme Yöneticiliği. Yenilenmiş 4. Baskı. Konya: Selçuk Üniversitesi İktisadi ve İdari Bilimler Fakültesi

Teng, Bing-Sheng (2007). Corporate Entrepreneurship Activities Through Strategic Alliances: A Resource-Based Approach Toward Competitive Advantage. Journal of Management Studies. Vol. 44, No: 1, s. 119-142.

Tutar, Hasan, Küçük Orhan (2003). Girişimcilik ve Küçük İşletme Yönetimi. İstanbul: Seçkin Yayıncilık.

Ülgen, Hayri ve Mirze, S. Kadri (2016). “İşletmelerde Stratejik Yönetim”. (8. Baskı). İstanbul: Beta Yayınları. 

Değer ve Stratejik Amaçlarının İçerik Analizi. Journal of Research in Economics, Politics \& Finance. 3(1):18-31 DOI: 10.30784/epfad.401092

Want, Jerome H. (1986). "Corporate Mission, The Intangible Contributor to Performance". Management Review, August, 46-50.

Ward, Thomas B. (2004). Cognition, Creativity, and Entrepreneurship. Journal of Business Venturing. Vol. 19, s. 173-188.

Weber, Robert Philip(1990). Basic Content Analysis. Sage, Second Edition, London.

Yurtseven, H. R. (1988). Stratejik Yönetim Sürecinde Misyon Kavramı. Yönetim. 9 (29). 26-33.

Zahra, S. A. (1996). Goverance, ownership, and corporate entrepreneurship: The moderating impact of industry technological opportunities. Academy of management journal. 39(6), 1713-1735

Zampetakis, L. A., \& Moustakis, V. (2006). Linking creativity with entrepreneurial intentions: A structural approach. The International Entrepreneurship and Management Journal, 2(3), 413428.

ZOLTAN, J.Acs vd. (2001). "Entrepreneurship, Globalization and Public Policy". Journal of International Management. Vol.7.

www.adabank.com.tr, Erişim Tarihi: 30.08 .2020

www.akbank.com.tr, Erişim Tarihi: 30.08.2020

www.anadolubank.com.tr, Erişim Tarihi: 30.08 .2020

www.bankofchine.com.tr, Erişim Tarihi: 30.08.2020

www.burgan.com.tr, Erişim Tarihi: 30.08.2020

www.citibank.com.tr, Erişim Tarihi: 30.08.2020

www.db.com, Erișim Tarihi: 30.08.2020

www.denizbank.com, Erişim Tarihi: 30.08.2020

www.fibabanka.com.tr, Erişim Tarihi: 30.08.2020

www.halkbank.com.tr, Erişim Tarihi: 30.08.2020

www.Ing.com.tr, Erişim Tarihi: 30.08.2020

www.isbank.com.tr, Erişim Tarihi: 30.08.2020

www.sekerbank.com.tr, Erişim Tarihi: 30.08.2020

www.teb.com.tr, Erişim Tarihi: 30.08.2020

www.tu.bk.mufg.jp, Erişim Tarihi: 30.08.2020

www.turkishbank.com.tr, Erişim Tarihi: 30.08.2020

www.vakifbank.com.tr, Erişim Tarihi: 30.08.2020

www.yapikredi.com.tr, Erişim Tarihi: 30.08 .2020

www.ziraatbank.com.tr, Erişim Tarihi: 30.08.2020 


\section{EXTENDED ABSTRACT}

\section{Entrepreneurship Characteristics Of Financial Enterprises According To The Mission And Vision Expression Components In The Context Of Strategic Management}

\section{Introduction}

Enterprise; It is expressed as an economic unit that creates a whole as a place, title, capital, accounting and organization separate from the private property of its owner to meet human needs and engages in continuous production activities (Şimşek and Çelik, 2012, p.11). Entrepreneurship is an essential need for the growth of developing economies; this phenomenon is a global concept including developed economies today (Zoltan et al., 2001: 235-245). It can be said that Schumpeter has made the most important and well-known contribution to the theory of entrepreneurship by defining the entrepreneur as an individual who offers innovation in his book titled "The Theory of Economic Development" (Aidis, 2003: 4). The personality traits of entrepreneurs have been expressed differently by many different authors. Innovative (Herron, 1992; Geisler, 1993; Drucker, 1998; Daft, 2005; Hisrich et al., 2005; Hitt et al., 2005; Küçük, 2005), risk taker (Geisler, 1993; Johnson /Hayes, 19961.1 Motivation Drucker, 1998; Hisrich et al., 2005; Hitt et al., 2005; Küçük, 2005; Zhao et al., 2005; Hewison/Badger, 2006), change-oriented (Luchsinger/Bagby, 1987; Herron, 1992; Hisrich et al., 2005; Hitt et al., 2005), focused on opportunities (Corbett/Hmieleski, 2005; Hitt et al., 2005) and creative (Daft, 2005; Hitt et al., 2005; Hewison/Badger, 2006). In addition, with regard to the characteristics of entrepreneurs, low rates of advanced communication skills (Hitt et al., 2005), proactivity (Hisrich et al., 2005), conscientiousness, high achievement motivation (Daft, 2005) and persistence in their decisions. (Hitt et al., 2005) (Bozkurt et al., 2012:232,233).

\section{Data Set and Method}

The aim of this study is to examine the entrepreneurial characteristics of 34 entrepreneurs in the banking and finance sector as of August 2020, based on the framework mentioned in the theoretical section, according to the elements that make up the mission and vision statements on their websites, and to determine at what level they reflect entrepreneurship; Bank enterprises were selected as a sample in the universe of all banks and financial enterprises operating in Turkey. Qualitative research technique was used as the method of this research. In this context, bank enterprises were selected as a sample in the universe of all banks and financial enterprises operating in Turkey. For the purposes of the research, the mission-vision and the expressions of the mission and vision obtained from the expressions related to the organizational value were examined with the help of qualitative content analysis with the help of the web pages of the banks and finance companies operating in Turkey. Content analysis; (Qualitive Content Analysis: QCA) is a method that aims to obtain some findings about some dimensions and sections of the new unknown social reality that does not exist by moving from the quantitative and qualitative dimensions of the existing texts. It is tried to draw conclusions about the factors that are not directly observed from the results observed in the contents of the communication (Gökçe, 2006: 20).

\section{Empirical Findings}

In this study, the entrepreneurial characteristics of bank enterprises were evaluated according to the dimensions determined in the literature. Mission and vision statements mirror the behavioral role of a business. In this context, the entrepreneurial characteristics explained in the theoretical framework were used to evaluate the entrepreneurial characteristics of bank businesses operating in Turkey depending on the mission and vision statements. In this context, the classification of banks in the Turkish Banking Sector made by the TBB was taken as a basis; In line with this classification, the 
findings obtained in order to reveal the entrepreneurial characteristics of the relevant banks depending on the mission and vision statement components were evaluated.

\section{Discussion and Conclusion}

In this study, entrepreneurial characteristics were evaluated with the help of the mission and vision statements shared on the websites of the bank enterprises -except industrial and development banks- shared on the website of the TBB operating in Turkey. In this direction, by scanning the relevant literature, it is meaningful to summarize the orientation in the mission and vision statements in expressing the entrepreneurial characteristics of the enterprises; dimensions such as risk taking, leadership, innovation, creativity, strength, proactivity, research and development, success and competitiveness were defined and the mission and vision statements of these banks were examined according to these dimensions.

As a result of the findings obtained in the study, there is no mission and vision statement shared on the websites of some banks. It is seen that the banks in question, which share mission and vision statements on their websites, mostly reflect their entrepreneurial characteristics in their vision statements. Often in both mission and vision statements; While the concepts of leadership, proactivity, innovation and competitiveness come to the fore; Although rarely, strength and success dimensions were also encountered. When analyzed in terms of Domestic Capital Deposit Banks, while leadership is at the forefront; Although Foreign Capital Deposit Banks also come to the fore with leadership; In addition, innovation, strength and competitiveness came to the fore. No dimension was found in the mission and vision statement of the United Fund Bank, which is the Bank Transferred to the Savings Deposit Insurance Fund.

In addition, when evaluated in terms of Foreign Capital Banks Established in Turkey, innovation and leadership aspects come to the fore; it is rarely seen that there are also strength, proactivity and creativity dimensions. When the Foreign Capital Banks Opening Branches in Turkey are examined, it is seen that the dimensions of innovation, strength, leadership and success come to the fore. This study is an important study in terms of being more selective when creating mission and vision statements of bank enterprises. When the findings obtained from the study are evaluated, it is seen that the banking enterprises operating in Turkey attach importance to leadership, competitiveness and innovation. In terms of both mission and vision statements, it is seen that the dimensions of Risk Taking and Research and Development are almost never encountered and are not preferred. Likewise, it is noteworthy that the dimensions of creativity, proactivity and success are less preferred. Of course, it cannot be said that they do not take risks, do not attach importance to Research and Development, are not creative, pioneers, because they do not specify in their mission and vision statements; but it is still thought provoking. Researchers who will work in this field can investigate whether bank enterprises prefer these dimensions, if they do not, why they do not, and if they do, why they are not included in their mission and vision statements. 